University of Nebraska - Lincoln

DigitalCommons@University of Nebraska - Lincoln

2000

Restoring Ecological Integrity of Great Rivers: Historical

Hydrographs Aid in Defining Reference Conditions for the

Missouri River

David L. Galat

U.S. Geological Survey

Robin Lipkin

University of Missouri, Columbia

Follow this and additional works at: https://digitalcommons.unl.edu/usgsstaffpub

Part of the Earth Sciences Commons

Galat, David L. and Lipkin, Robin, "Restoring Ecological Integrity of Great Rivers: Historical Hydrographs Aid in Defining Reference Conditions for the Missouri River" (2000). USGS Staff -- Published Research. 18. https://digitalcommons.unl.edu/usgsstaffpub/18

This Article is brought to you for free and open access by the US Geological Survey at DigitalCommons@University of Nebraska - Lincoln. It has been accepted for inclusion in USGS Staff -- Published Research by an authorized administrator of DigitalCommons@University of Nebraska - Lincoln. 


\title{
Restoring ecological integrity of great rivers: historical hydrographs aid in defining reference conditions for the Missouri River
}

\author{
David L. Galat ${ }^{1}$ \& Robin Lipkin ${ }^{2}$ \\ ${ }^{1}$ U.S. Geological Survey, Biological Resources Division, Missouri Cooperative Fish and Wildlife Research Unit, \\ 302 Anheuser-Busch Natural Resources Building, University of MO, Columbia, MO 65211-7240, U.S.A. \\ ${ }^{2}$ The School of Natural Resources, 302 Anheuser-Busch Natural Resources Building, University of Missouri, \\ Columbia, MO 65211-7240, U.S.A.
}

Key words: ecological reference, flood pulse, flow regulation, hydrology, Range of Variation Approach

\begin{abstract}
Restoring the ecological integrity of regulated large rivers necessitates characterizing the natural flow regime. We applied 'Indicators of Hydrologic Alteration' to assess the natural range of variation of the Missouri River's flow regime at 11 locations before (1929-1948) and after (1967-1996) mainstem impoundment. The $3768 \mathrm{~km}$ long Missouri River was divided into three sections: upper basin least-altered from flow regulation, including the lower Yellowstone River; middle basin inter-reservoir, and lower basin channelized. Flow regulation was associated with a reduction in magnitude and duration of the annual flood pulse, an increase in magnitude and duration of annual discharge minima, a reduction in frequency of annual low-flow pulses, earlier timing of March-October low-flow pulses, and a general increase in frequency of flow reversals with a reduction in the rate of change in river flows. Hydrologic alterations were smallest at two least-altered upper-basin sites and most frequent and severe in interreservoir and upper-channelized river sections. The influence of reservoir operations on depressing the annual flood pulse was partially offset by tributary inflow in the lower $600 \mathrm{~km}$ of river. Reservoir operations could be modified to more closely approximate the 1929-1948 flow regime to establish a simulated natural riverine ecosystem. For inter-reservoir and upper channelized-river sections, we recommend periodic controlled flooding through managed reservoir releases during June and July; increased magnitude, frequency and duration of annual high-flow pulses; and increased annual rates of hydrograph rises and falls. All of the regulated Missouri River would benefit from reduced reservoir discharges during August-February, modified timing of reservoir releases and a reduced number of annual hydrograph reversals. Assessment of ecological responses to a reregulation of Missouri River flows that more closely approximates the natural flow regime should then be used in an adaptive fashion to further adjust reservoir operations.
\end{abstract}

\section{Introduction}

So paramount is a river's flow regime as an underpinning to ecological integrity that its protection or restoration has been accorded 'the natural flow paradigm' (Poff et al., 1997; Richter et al., 1997). Alteration of the natural flow regime through impoundment and flow regulation has severely compromised the ecological health (sensu Karr \& Chu, 1999) of most of the world's rivers. This is pervasive for large and great rivers in developed countries because of their long association with human activities (Davies \& Walker, 1986; Benke, 1990; Bravard \& Petts, 1996). Rehabil- itation of the hydrological and ecological integrity of large rivers is therefore a major thrust of contemporary fluvial ecology (Gore, 1985; Boon et al., 1992; National Research Council, 1992; Calow \& Petts, 1992).

Assessment is a fundamental aspect of characterizing, conserving or recovering the ecological integrity of fluvial hydrosystems and benchmarks or reference conditions are necessary to quantify what constitutes 'healthy' or 'integrity.' Hughes (1995) gave six approaches for determining reference conditions. These include: regional reference sites, historical data, paleoecological data, experimental laboratory data, 
quantitative models and best professional judgement. Assessing and restoring ecological integrity of large rivers precludes use of regional reference systems as there is only one Danube or Missouri River. Additionally, biomonitoring, experimental studies and quantitative models of large rivers are limited relative to wadeable streams due to their size and sampling difficulties (Johnson et al., 1995; Reash, 1998). However, long-term hydrological records are often available for large rivers (Sparks, 1992).

An initial consideration to realize fluvial restoration is to reregulate the natural flow regime (National Research Council, 1992; Gore \& Shields, 1995; Stanford et al., 1996; Poff et al., 1997), since attempts to reestablish a river's biological integrity are doomed without recreating the underlying physical template. Consequently, 'managed flooding' is now recommended to naturalize river flows and their associated ecological processes in some large rivers (Michener \& Haeuber, 1998).

Our objective was to assess ecologically relevant components of the Missouri River's flow regime and their longitudinal variability before and after mainstem regulation. We use this information to provide initial guidelines for restoring a more natural hydrograph to enhance the ecological integrity of the river's imperiled biota.

\section{Missouri River hydrosystem}

The Missouri River is the longest river in the conterminous United States. It extends $3768 \mathrm{~km}$ from southwest Montana to the Mississippi River, near St. Louis, Missouri (Figure 1). Its drainage basin encompasses about one-sixth of the conterminous United States $\left(1371000 \mathrm{~km}^{2}\right)$ and is largely semi-arid, resulting in a low discharge relative to basin area. Mean annual Missouri River discharge per unit drainage area from 1951 to 1980 was about four times less $\left(0.0016 \mathrm{~m}^{3}\right.$ $\mathrm{s}^{-1} \mathrm{~km}^{-2}$ ) than for the adjacent upper Mississippi River $\left(0.0065 \mathrm{~m}^{3} \mathrm{~s}^{-1} \mathrm{~km}^{-2}\right.$; data from Hedman \& Jorgensen, 1990).

Public demands to improve navigation, irrigate the arid Great Plains, control devastating floods and generate electricity began in earnest on the Missouri River in the early 1900s. Today, this highly regulated river can be divided into three approximately equal length sections. The upper $1241 \mathrm{~km}$ represents a 'least-altered' section relative to the remaining river. Although four mainstem dams and reservoirs are present - Helena,

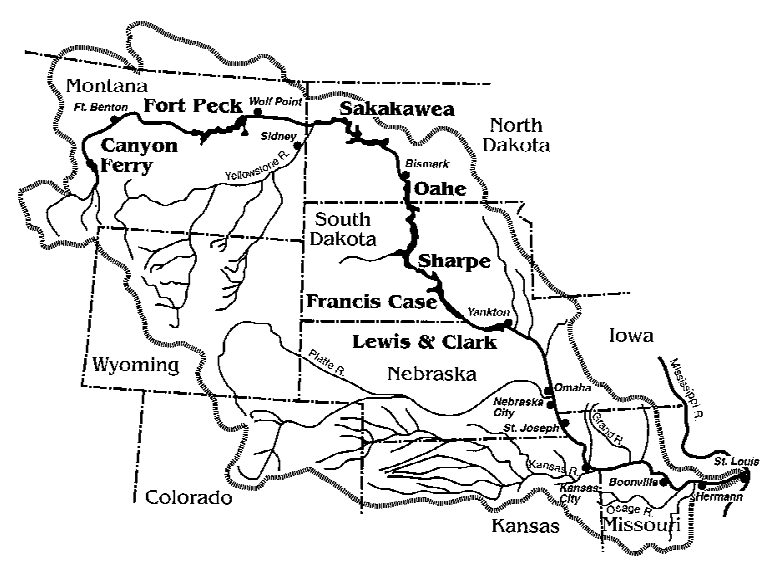

Figure 1. Map of the Missouri River basin (thick broken line), the Missouri River and its major tributaries, mainstem reservoirs (names in bold), and locations of gauging stations where historical flow records were analyzed.

Hauser, Holter and Canyon Ferry - their usable capacity $\left(2.7 \mathrm{~km}^{3}\right)$ is only $3 \%$ of the downriver mainstem reservoirs. The $1233 \mathrm{~km}$ long middle or 'interreservoir' section was impounded between 1937 and 1963 by a cascade of six large mainstem reservoirs (total gross volume: $90.7 \mathrm{~km}^{2}$; total average annual discharge: $100.5 \mathrm{~km}^{3} \mathrm{yr}^{-1}$ ). Flows in the $1212 \mathrm{~km}$ long lower section are regulated by upstream reservoirs. Channel-floodplain morphology in the lower section from Sioux City, Iowa $(1178 \mathrm{~km})$, to the mouth was also altered by channelization, bank stabilization and levee construction and will be referred to as the 'channelized' section.

System impoundment, flow regulation, channelization, levee construction, and other basin developments and their impacts on the system's ecology have been considerable and are chronicled elsewhere (see Hesse et al., 1989; Schmulbach et al., 1992; Galat \& Frazier, 1996 and references therein). Collectively, Missouri River basin development has contributed to listing as endangered, threatened, or rare by state or federal agencies seven species of plants, six insects, two mussels, 16 fishes, four reptiles, 14 birds and three mammals (Whitmore \& Keenlyne, 1990). The conservation organization, American Rivers, listed the Missouri River as North America's most endangered river in 1997 (American Rivers, 1997). Re-establishing a semblance of the natural flow regime is an essential element to restore the Missouri River's ecological integrity; characterizing pre-regulation hydrologic variability is an initial step. 


\section{Methods}

The Range of Variation Approach, or RVA, was developed by The Nature Conservancy (Richter et al., 1997) to assess and define river ecosystem management targets based on a statistical characterization of ecologically relevant hydrologic parameters (Richter et al., 1996). The hydrologic parameters used in the RVA comprise the 'Indicators of Hydrologic Alteration,' or IHA, method (Richter et al., 1996). These parameters reflect five fundamental attributes of river flow that have profound ecological significance: magnitude, timing, frequency, duration and rate of change of discharge (Richter et al., 1996, 1998; Poff et al., 1997; Scott et al., 1997). The IHA method calculates 32 hydrologic parameters for each year of flow record (Table 1). Measures of central tendency (mean, median) and dispersion (range, standard deviation, percentiles, coefficient of variation $(\mathrm{CV})$ and coefficient of dispersion (CD)) are used to characterize inter-annual variation before (reference period) versus after the system has been altered by human activities (Richter et al., 1996). A fundamental concept of the RVA is that post-regulation river flows should be managed to fall within the targeted range of IHA values at the same frequency as the pre-regulation flows (Richter et al., 1997).

Richter et al. (1997) recommended six steps for setting, implementing and refining flow management targets for a specific river or reaches within a river. We applied the first two steps to evaluate contemporary Missouri River hydrology relative to historical conditions. First, we characterized the natural range of flow variation (Step 1) for the Missouri River using IHA before and after mainstem flow regulation, referred to hereafter as pre- and post-regulation, respectively. Second, initial flow management targets were identified for these hydrologic parameters using the RVA approach.

River-flow data were analyzed from gauging stations above (least-altered), between (inter-reservoir) and below (channelized) the large mainstem reservoirs. Comparing hydrologic parameters before and after flow regulation at stations above major reservoirs provides an estimate of natural temporal variability between the two time periods. It also enabled us to evaluate the applicability of relatively least-altered sites as spatial references for distant locations below large mainstem reservoirs.

The IHA software uses daily flow data input by water year (October 1-September 30). The first year of continuous daily flow records for most mainstem Missouri River stations was water year 1929 (October 1928-September 1929). We searched the U.S. Geological Survey's (USGS) stream-flow records to locate mainstem Missouri River stations meeting three criteria: 1. a minimum of 13 years of continuous flow records both before and after reservoir construction; 2. location of stations within each of the least-altered, inter-reservoir and channelized-river sections; 3. concentration of stations in river sections where input from major tributaries was highest. Ten of the 24 mainstem gauging stations met these criteria.

Gauging stations are identified by their location $(\mathrm{km})$ upstream from the mouth of the Missouri River followed by a two-letter abbreviation of the station name. Least flow-altered sites are identified in bold typeface. Inter-reservoir stations and station 1297YT, just below the most downstream reservoir (Lewis and Clark), are identified by normal type face and stations in the channelized section are distinguished by italics. We also included one tributary, least-altered station in our analysis: Sidney, Montana (2592SN), $47 \mathrm{~km}$ upstream from the Yellowstone River's confluence with the Missouri. The Yellowstone is the longest freeflowing, high-quality, large river in the conterminous U.S. (Benke, 1990; White \& Bramblett, 1993), and has a greater discharge than the mainstem Missouri at their confluence (Table 2). Stations 3336FB and 2592SN are affected by human activities (e.g. small impoundments and water diversions), but their flow regimes are little altered relative to other mainstem Missouri River sites (White \& Bramblett, 1993; Scott et al., 1997; Shields et al., 1997).

Construction of Ft. Peck $(2850 \mathrm{~km})$, the first dam on the mainstem Missouri, began in 1937. Hesse \& Mestl (1993) reported that its early operation did not affect the hydrograph at Bismarck, North Dakota (2115BM), until 1948 and they defined the preregulation period for the entire river as 1929-1948. We adopted this interval, but recognize that filling and operation of Ft. Peck Dam may have influenced river flow at the Wolf Point station (2738WP) between Ft. Peck Dam and 2115BM. The remaining mainstem reservoirs were constructed between 1953 and 1963 and the six-dam system commenced operation in 1967 (Ferrell, 1993); we defined the post-regulation period as 1967-1996. Flow data were incomplete over the 50 year record for three of the 11 stations. One year of pre-regulation flows was absent from 905NC (1929) and two years each from 2592SN (1932-1933) and 1297YT (1929-1930). 
Table 1. Summary of the 32 hydrologic parameters used in the Indicators of Hydrologic Alteration (IHA) method for the Missouri and lower Yellowstone rivers. Sources: Richter et al. (1996, 1998)

\begin{tabular}{|c|c|c|}
\hline IHA statistics group & & Hydrologic parameters (number) \\
\hline Group 1: & $\begin{array}{l}\text { Magnitude of monthly } \\
\text { discharge conditions }\end{array}$ & $\begin{array}{l}\text { Median discharge for each calendar } \\
\text { month (12) }\end{array}$ \\
\hline Group 2: & $\begin{array}{l}\text { Magnitude and duration of } \\
\text { annual extreme discharge } \\
\text { conditions }\end{array}$ & $\begin{array}{l}\text { Annual median discharge maxima } \\
\text { and minima averaged over 1-day, } \\
\text { 3-day, 7-day, 30-day and 90-day } \\
\text { intervals (10) }\end{array}$ \\
\hline Group 3: & $\begin{array}{l}\text { Timing of annual extreme } \\
\text { discharge conditions }\end{array}$ & $\begin{array}{l}\text { Median Julian date of each annual } \\
\text { (Jan-Dec) 1-day maximum and } \\
\text { minimum discharge and median } \\
\text { Julian date of each seasonal } \\
\text { (Mar-Oct) 1-day minimum } \\
\text { discharge (3) }\end{array}$ \\
\hline Group 4: & $\begin{array}{l}\text { Frequency and duration of } \\
\text { high- and low-flow pulses }\end{array}$ & $\begin{array}{l}\text { Median number and median duration } \\
\text { of high and low discharge pulses } \\
\text { each year (4) }\end{array}$ \\
\hline Group 5: & $\begin{array}{l}\text { Rate and frequency of } \\
\text { hydrograph changes }\end{array}$ & $\begin{array}{l}\text { Mean of all positive and negative } \\
\text { differences between consecutive } \\
\text { daily discharge values and mean } \\
\text { number of flow reversals (3) }\end{array}$ \\
\hline
\end{tabular}

\section{Indicators of hydrologic alteration calculations}

We added an additional variable to the Group 3 statistics (Table 1): Julian date (JD) of the vegetation 'growing season' 1-day minimum flow where the growing season was defined as March 1-October 31 (JD 122305). Minimum flows during this period are relevant to reproductive success of the federally endangered least tern (Sterna antillarum) and threatened piping plover (Charadrius melodus), which nest on exposed sand islands along the Missouri and its major tributaries (Smith, 1996; Bacon \& Rotella, 1998). Timing of sand island exposure is also important to nesting success of softshell turtles (Apalone spp., pers. comm., R. Bodie, Dept. Biol. Sci., University of Missouri), as is exposure of mud flats to germination of annual moist-soil plants (Galat et al., 1998). Additionally, most Missouri River fishes reproduce during the March-October interval (Galat et al., 1998) and shallow-water habitats are important nursery areas for many large-river fishes (Copp, 1991; Poizat \& Pont, 1996). It was not neces- sary to add a new variable to reflect the date of the growing season 1-day discharge maximum, because the maximum for the whole year at all stations always occurred between March and October.

Specific high and low discharge thresholds are user-defined in the IHA to compute the number and duration of high and low pulses relative to these flows. Richter et al. (1997) suggest a default definition of high pulses as $>75$ th percentile (\%ile) of all pre-dam flows and low pulses as $<25$ th\%ile of all pre-dam flows. We adopted this approach, but applied a more conservative criterion, defining the annual high-flow threshold at each station as the 75 th\%tile daily discharge for the month with the highest preregulation monthly median discharge. Conversely, the low-discharge threshold was set as the 25 th\%ile daily discharge for the month with the lowest pre-regulation monthly median discharge.

\section{Range of variability calculations}

Once IHA parameter values are calculated (Step 1), 
Table 2. Location (kilometers upstream from Missouri River mouth), drainage area, pre- (Oct 1929-Sep 1948) and post-flow (Oct 1967-Sep 1996) regulation mean annual discharge, and percent change in mean annual discharge from pre- to post-flow regulation at two stations on the Missouri and lower Yellowstone (2592SN) rivers upstream from large mainstem reservoirs (bold), three stations immediately below dams or between reservoirs, and six stations downstream from reservoirs in the channelized river (italics). Pre-flow regulation period is missing 1932-33 at km 2592SN, 1929-1930 at km 1297YT, and 1929 at km 905NC

\begin{tabular}{|c|c|c|c|c|c|}
\hline \multirow{2}{*}{$\begin{array}{l}\text { Name } \\
\text { (USGS station number) }\end{array}$} & \multirow{2}{*}{$\begin{array}{c}\text { Station } \\
\text { location } \\
(\mathrm{km}) \\
\text { and ID }\end{array}$} & \multicolumn{4}{|c|}{ Mean annual discharge $\left(\mathrm{m}^{3} \mathrm{~s}^{-1}\right)$} \\
\hline & & $\begin{array}{c}\text { Drainage } \\
\text { area } \\
\left(\mathrm{km}^{2}\right)\end{array}$ & $\begin{array}{c}1929- \\
1948\end{array}$ & $\begin{array}{c}1967- \\
1996\end{array}$ & $\begin{array}{l}\text { Percent } \\
\text { change }\end{array}$ \\
\hline $\begin{array}{l}\text { Fort Benton, MT } \\
(06090800)\end{array}$ & 3336FB & 64100 & 175.1 & 228.4 & 30.4 \\
\hline $\begin{array}{l}\text { Wolf Point, MT } \\
(06177000)\end{array}$ & 2738WP & 213131 & 212.0 & 300.1 & 41.6 \\
\hline $\begin{array}{l}\text { Sidney, MT YSR } \\
(06329500)\end{array}$ & 2592SN & 178977 & 332.6 & 358.4 & 7.8 \\
\hline $\begin{array}{l}\text { Bismarck, ND } \\
(06342500)\end{array}$ & 2115BM & 482776 & 583.9 & 698.5 & 19.6 \\
\hline $\begin{array}{l}\text { Yankton, SD } \\
(06467500)\end{array}$ & 1297YT & 723905 & 692.8 & 812.8 & 17.3 \\
\hline $\begin{array}{l}\text { Omaha, NE } \\
(06610000)\end{array}$ & $991 O M$ & 846306 & 771.5 & 1012.2 & 31.2 \\
\hline $\begin{array}{l}\text { Nebraska City, NE } \\
(06807000)\end{array}$ & $905 N C$ & 1072154 & 913.7 & 1193.8 & 30.6 \\
\hline $\begin{array}{l}\text { St. Joseph, MO } \\
(06818000)\end{array}$ & $721 S J$ & 1088577 & 1007.4 & 1386.4 & 37.6 \\
\hline $\begin{array}{l}\text { Kansas City, MO } \\
(06893000)\end{array}$ & $589 K C$ & 1256668 & 1240.9 & 1673.0 & 34.8 \\
\hline $\begin{array}{l}\text { Boonville, } M O \\
\text { (06909000) }\end{array}$ & $317 B V$ & 1299403 & 1487.0 & 2020.4 & 35.9 \\
\hline $\begin{array}{l}\text { Hermann, } M O \\
(06934500)\end{array}$ & $158 H M$ & 1357678 & 1955.6 & 2629.6 & 34.5 \\
\hline
\end{tabular}

the RVA recommends that flow management 'targets' for each hydrologic parameter be based on a river management team's selected ranges of natural variation for that parameter (Step 2). In the absence of specific ecological information to identify these targets, Richter et al. (1997) recommend using \pm 1 standard deviation (SD) of pre-development hydrologic parameters as initial targets; we follow this general approach. However, hydrologic data are often skewed so that \pm 1 SD falls outside the range of observed values. This occurred for various parameters within Groups 1-4 of the IHA statistics for the Missouri River 
data set. Consequently, we report median (50th\%ile) values rather than means for parameters within Groups $1-4$ and use the 25th and 75th\%iles as our initial flow management targets. The mean and \pm 1 SD were used for Group 5 parameters (rise rate, fall rate and number of flow reversals). We report each IHA parameter as the percent change in medians or means and CDs or $\mathrm{CVs}$ from the pre-regulation to post-regulation period:

$$
\begin{aligned}
\% \mathrm{CHG}= & ((\text { post-regulation value }) \\
& -(\text { pre-regulation value })) / \\
& (\text { pre-regulation value }) * 100 .
\end{aligned}
$$

See Galat \& Lipkin (1999) for numerical values of each variable.

Using measures of natural dispersion based on pre-regulation data as flow 'targets' evaluates if postregulation hydrologic conditions occur at the same frequency as before regulation (Richter et al., 1998). Pre-regulation annual values for hydrologic parameters fall within the $25-75$ th \%ile values $50 \%$ of the time and within \pm 1 SD about $67 \%$ of the time. Thus, for post-regulation IHA observations to meet target criteria, only one-half to two-thirds of annual values are expected to fall within the pre-development flow regime. The degree to which the selected pre-regulation RVA measure of dispersion is not attained is an estimate of 'hydrologic alteration' (Richter et al., 1998). We follow Richter et al.'s (1998) example and report the percent of hydrologic alteration as:

$$
\begin{aligned}
\% \mathrm{HA}= & ((\text { Observed }- \text { Expected }) / \\
& \text { Expected }) * 100 .
\end{aligned}
$$

'Observed' is the count of post-regulation years the hydrologic parameter was observed within the preregulation 25-75th \%iles or $\pm 1 \mathrm{SD}$ of the preregulation mean. 'Expected' is the count of postregulation years the hydrologic parameter is expected within the pre-regulation 25-75th \%iles or $\pm 1 \mathrm{SD}$ of the mean, which by definition, is either 50 or $67 \%$, respectively. Thus, $\% \mathrm{HA}=0$, when the observed frequency of post-regulation years falling within the pre-regulation target range is the same as expected during the pre-regulation period. When $\% \mathrm{HA}>0$, post-regulation annual parameter values fell within the RVA target window more often than expected, while $\% \mathrm{HA}<0$ for a post-regulation parameter indicates annual values fell within the RVA target window less often than expected. We further abstract hydrologic alteration among stations by dividing \%HA values (absolute) into four classes of equal range: $0=0$ $25 \%$, low flow alteration; $1=26-50 \%$, moderate flow alteration; $2=51-75 \%$, high-flow alteration; and $3=$ 76-100\%, extreme flow alteration. These ranks were first averaged over the hydrologic indicators within each of the five IHA groups and then the group means averaged to yield an index of overall hydrologic alteration for each station. Caution is advised not to overinterpret this summary index, as combining offsetting variables might yield similar overall \%HAs among stations which exhibit widely different causes of impairment. Management actions should rely on consideration of each of the 32 individual indicators.

\section{Results}

Mean annual discharge over the study period (19291996) increased gradually from $3336 \mathbf{F B}$ to $9910 \mathrm{M}$, as only a few major tributaries contribute flow in this section (e.g. Yellowstone River, Table 2). Downriver from 991OM, flow increased more steeply with the input of several tributaries (Platte, $957 \mathrm{~km}$; Kansas, $591 \mathrm{~km}$; Grand, 402 km; Chariton, 366 km; Osage, 209 km; and Gasconade, $168 \mathrm{~km}$ ). Although the lower $991 \mathrm{~km}$ of river drains only about $38 \%$ of the total Missouri River catchment, it contributed $61 \%$ of the 50 year mean annual discharge at $158 \mathrm{HM}$.

Mean annual discharge for the 30 year postregulation period was higher at all stations than for the 20 years before mainstem dams operated as a complex (Table 2). This increase in discharge was $<10 \%$ at 2592SN (Yellowstone River), but about $30 \%$ higher at $3336 \mathbf{F B}$. The discharge increase at the six channelized stations on the lower Missouri River ranged from about 30 to $38 \%$. The greatest increase in post-regulation discharge was observed at $2738 \mathrm{WP}$, below Ft. Peck Dam. This appeared to be an artifact of including reservoir filling in the 1929-1948 pre-regulation interval.

\section{Magnitude of monthly discharge}

The general pattern of mean monthly discharge at all stations before mainstem impoundments were operational was an extended period of low flow from August through February (Figure 2). Mean discharge increased beginning in March at most stations, showed a small peak in April between 2115BM and 589KC, and was highest during June throughout the river continuum. The annual flood pulse was unimodal at 

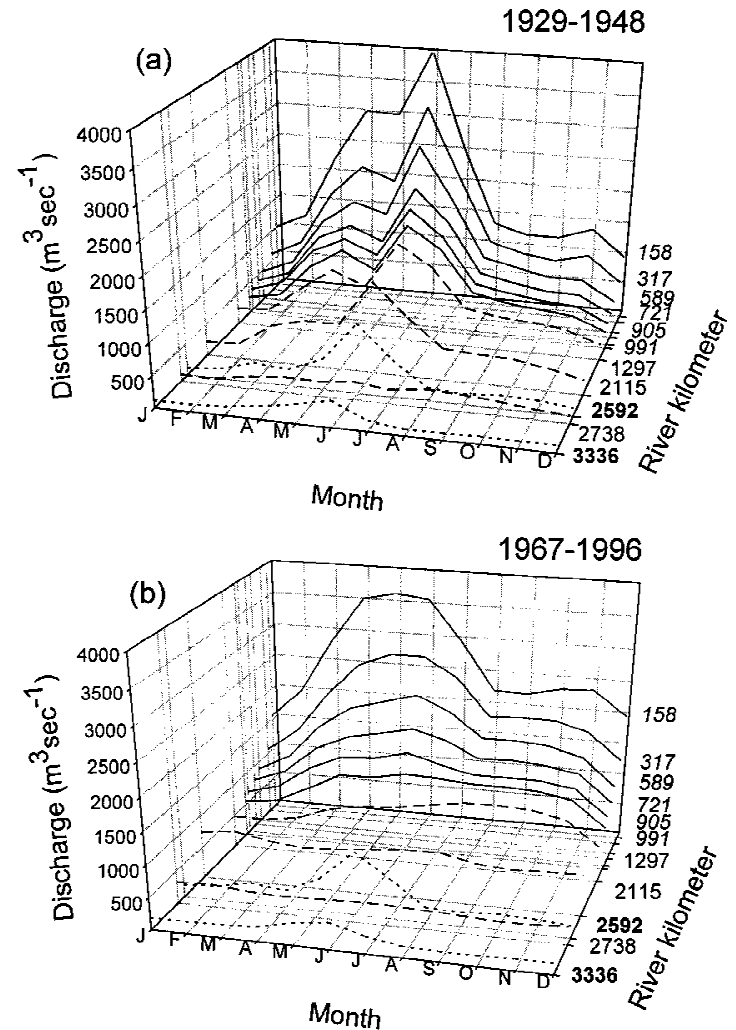

Figure 2. Mean monthly discharge before (a, Oct 1929-Sep 1948) and after (b, Oct 1967-Sep 1996) flow regulation along the mainstem Missouri and lower Yellowstone rivers. Stations above large mainstem reservoirs are indicated by dotted lines, those between and immediately below reservoirs by dashed lines, and those below reservoirs in the channelized Missouri River are identified by solid lines. River kilometer is distance above the Missouri River mouth. Station 2592 (Sidney, MT) is on the undammed lower Yellowstone River.

least-altered site 3336FB (June peak), weakly bimodal at 2738WP and 2115BM (April, June peaks), strongly bimodal at 2592SN (March, June peaks) and also at 1297YT, 991OM and 905NC, but with April and June peaks. The bimodal flood-pulse pattern weakened downriver from 991OM, gradually becoming nearly unimodal again at the lowermost station (158HM). A small November flow pulse was also observed before flow regulation at the two lowermost stations $(317 \mathrm{BV}, 158 \mathrm{HM})$. The absence of a distinct flood pulse at $2738 \mathrm{WP}$ relative to $\mathbf{3 3 3 6} \mathbf{F B}$ and $\mathbf{2 5 9 2 S N}$ (Figure 2) again appeared to be a result of filling Ft. Peck reservoir in the 'pre-impoundment' period.

The general pattern of post-regulation flows was a stabilization of mean monthly discharge by an increase in August through February low flows and a reduction in June and July high flows (Figure 2,
Table 3). This change was absent at least-regulated stations (3336FB, 2592SN), most pronounced at interreservoir and upper-channelized-river sites, and less extreme at lower-channelized river sites $(589 \mathrm{KC}$ $158 \mathrm{HM}$ ). Once the mainstem dams became operational, the naturally bimodal flood-pulse became unimodal at all sites below reservoirs and the small fall pulse at sites $317 \mathrm{BV}$ and $158 \mathrm{HM}$ disappeared because of constantly high summer-autumn reservoir water releases.

August through February median monthly discharges at most stations were above the pre-regulation 75th\%ile flow interval more often than expected for post-regulation years (Table 3). April and July \%HA was often positive following flow regulation, indicating that more years were within the pre-regulation 25-75th\%iles than expected for many stations, but there was no consistent trend in \%HA for March, May or June. Flow variability (\% change in $\mathrm{CD}$ ) was lower following impoundment for most months and gauging stations.

Median flows for the peak discharge month of June decreased $16 \%$ at least-altered station 2592SN between the two time intervals, the $\mathrm{CD}$ increased by $50 \%$, and $27 \%$ fewer years were within the 1967-1996 target window for June discharge (Figure 3). In contrast, median June discharge increased $37 \%$ at $\mathbf{3 3 3 6 F B}$, the CD was less, and $20 \%$ fewer years than expected were within the 1929-1948 2575 th\%iles. Decreases in median June discharge attributed to flow regulation were highest at inter-reservoir sites 2115BM and 1297YT and - moving downriver through the channelized reach - became progressively smaller (Figure 3 ). Median June flows decreased $<10 \%$ following impoundment at channelized-river stations $721 \mathrm{SJ}, 589 \mathrm{KC}, 317 \mathrm{BV}$ and $158 \mathrm{HM}$, while variability in June discharge decreased by $\geq 45 \%$ (Figure 3, Table 3). Fewer post-regulation years than expected were within the pre-regulation 25-75th\%iles for June discharge at most stations above $905 \mathrm{NC}$ (except 2738WP). The number of years where June discharge was outside the pre-regulation target window generally decreased downriver until there was no difference between the two time intervals at $905 \mathrm{NC}$ (Figure 3). Below $905 \mathrm{NC}$, a higher number of postregulation years were within the pre-regulation June flow 25-75th\%iles than expected. 
Table 3. Percent change in median, coefficient of dispersion, and hydrologic alteration of monthly discharge between pre- (Oct 1929-Sep 1948) and post-flow regulation (Oct 1967-Sep 1996) periods along the Missouri and lower Yellowstone (2592SN) rivers. Station locations are kilometers above Missouri River mouth. Station numbers in bold type are the least flow-altered, those in regular type are inter-reservoir or immediately below reservoirs, and those in italics are below reservoirs in the channelized river. See text for how hydrologic alteration was calculated

\begin{tabular}{lrrrrrrrrrrrr}
\hline Station & Jan & Feb & Mar & Apr & May & Jun & Jul & Aug & Sep & Oct & Nov & Dec \\
\hline \multicolumn{2}{c}{ Median } & & & & & & & & & & & \\
3336FB & 77 & 72 & 45 & 21 & 21 & 37 & 105 & 85 & 51 & 36 & 34 & 48 \\
$2738 W P$ & 285 & 366 & 90 & -12 & 30 & -6 & 64 & 47 & 100 & 77 & 92 & 230 \\
2592SN & 49 & 68 & -12 & 24 & 11 & -16 & -7 & 17 & 42 & 35 & 26 & 70 \\
$2115 B M$ & 314 & 272 & 18 & 9 & -6 & -54 & -21 & 43 & 43 & 56 & 118 & 201 \\
$1297 Y$ Y & 128 & 97 & -15 & 5 & 19 & -43 & -18 & 62 & 88 & 157 & 143 & 126 \\
$991 O M$ & 106 & 108 & 13 & 14 & 31 & -27 & -7 & 65 & 83 & 120 & 128 & 165 \\
$905 N C$ & 63 & 52 & 14 & 23 & 32 & -19 & -15 & 55 & 59 & 67 & 97 & 128 \\
$721 S J$ & 71 & 61 & 22 & 32 & 47 & -7 & 2 & 63 & 90 & 75 & 103 & 123 \\
$589 K C$ & 55 & 50 & 10 & 22 & 44 & -3 & -4 & 68 & 88 & 98 & 95 & 129 \\
$317 B V$ & 70 & 63 & 0 & 27 & 50 & -4 & -6 & 64 & 79 & 80 & 107 & 117 \\
$158 H M$ & 47 & 81 & 19 & 37 & 48 & 0 & 5 & 55 & 67 & 76 & 101 & 93
\end{tabular}

Coefficient of dispersion (CD)

$\begin{array}{lrrrrrrrrrrrr}\text { 3336FB } & -61 & -29 & 18 & -54 & 4 & -17 & 10 & 63 & 15 & 46 & 2 & -50 \\ 2738 \mathrm{WP} & -84 & -81 & -55 & 28 & -56 & -48 & -52 & -68 & -75 & -50 & -27 & -81 \\ \mathbf{2 5 9 2 S N} & -25 & 17 & -6 & -28 & -4 & 50 & -21 & -19 & -39 & -26 & 25 & -44 \\ 2115 \mathrm{BM} & -67 & -56 & -52 & -60 & -36 & 9 & -49 & -47 & -49 & -12 & -8 & -48 \\ 1297 \mathrm{YT} & -25 & -51 & -69 & -79 & -63 & -55 & -72 & -17 & -48 & -65 & -37 & 46 \\ 991 O M & -8 & -35 & -38 & -67 & -47 & -43 & -45 & -23 & -52 & -53 & -12 & 54 \\ 905 N C & 17 & -17 & 73 & -44 & -32 & -28 & -27 & -35 & -41 & -36 & -9 & 45 \\ 721 S J & 40 & -8 & 27 & -46 & -19 & -46 & -46 & -23 & -48 & -53 & -14 & -7 \\ 589 \mathrm{KC} & 25 & 32 & 44 & -9 & -20 & -60 & -29 & -27 & -10 & -44 & -39 & -15 \\ 317 \mathrm{BV} & -15 & 45 & 25 & 2 & -42 & -63 & -15 & -27 & 20 & -24 & -37 & -17 \\ 158 \mathrm{HM} & -6 & 8 & 93 & -1 & -25 & -45 & -10 & -34 & 18 & -19 & 0 & -20\end{array}$

Hydrologic alteration (HA)

\begin{tabular}{lrrrrrrrrrrrr} 
3336FB & -87 & -93 & -47 & 67 & -53 & -20 & -27 & -80 & -67 & -33 & -40 & -73 \\
2738WP & -100 & -100 & -53 & 33 & 53 & 60 & -7 & 93 & 87 & 27 & -60 & -100 \\
2592SN & -93 & -87 & 40 & 27 & -7 & -27 & 20 & 0 & 7 & -13 & -47 & -53 \\
$2115 \mathrm{BM}$ & -100 & -100 & 27 & 33 & 13 & -60 & 60 & -47 & 0 & -13 & -47 & -100 \\
$1297 \mathrm{YT}$ & -100 & -80 & 60 & 67 & 47 & -80 & 87 & -87 & -87 & -87 & -87 & -100 \\
$991 O M$ & -100 & -87 & 60 & 87 & 0 & -13 & 80 & -100 & -100 & -100 & -73 & -100 \\
$905 N C$ & -93 & -47 & -40 & 33 & 7 & 0 & 73 & -87 & -100 & -100 & -73 & -93 \\
$721 S J$ & -93 & -40 & -27 & 47 & -13 & 27 & 67 & -80 & -87 & -100 & -80 & -87 \\
$589 K C$ & -80 & -47 & -20 & 20 & -7 & 40 & 60 & -60 & -87 & -100 & -73 & -80 \\
$317 B V$ & -67 & -53 & -13 & 33 & 13 & 40 & 40 & -67 & -87 & -73 & -67 & -73 \\
$158 H M$ & -13 & -33 & -47 & 7 & 7 & 47 & 40 & -67 & -67 & -67 & -53 & -53 \\
\hline
\end{tabular}

\section{Magnitude and duration of discharge extremes}

Patterns of annual discharge maxima and minima were similar among the 1-, 3-, 7-, 30- and 90-day averaging windows so we report only the 1-, 7- and 30-day results (Table 4). Post-regulation median discharge maxima for 1-, 7-, and 30-day intervals were between 12 and 23\% lower than before regulation at 2592SN on the Yellowstone River, but about 30\% higher at 


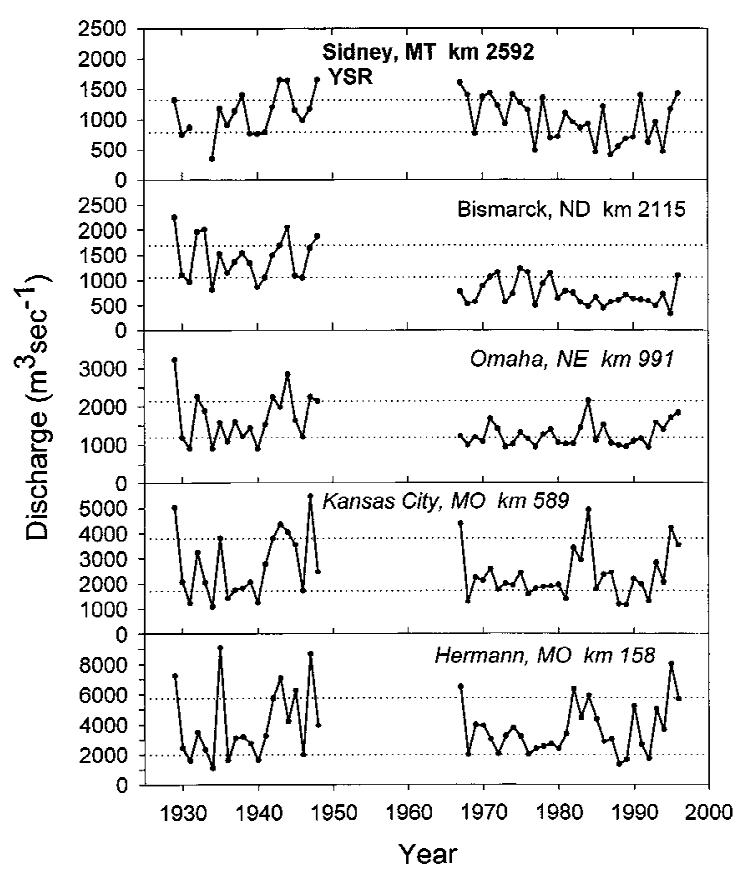

Figure 3. Median June discharge at five stations along the Missouri and lower Yellowstone rivers (YSR) before (1929-1948) and after (1967-1996) flow regulation. No flow records were available for Sidney, MT, during 1932-33. The horizontal dotted lines are the 25th (lower) and 75th (upper) percentiles for the pre-regulation interval and define a target range of acceptable hydrologic variability for post-regulation years. Numbers within panels identify station locations in kilometers above Missouri River mouth. Least-altered station names are in bold typeface, inter-reservoir stations are in normal typeface, and channelized river stations are in italics.

the least-regulated Missouri River station 3336FB (Table 4). Median annual maximum flows for the three averaging durations were nearly all less after regulation for inter-reservoir and channelized-river stations $2738 \mathrm{WP}$ to $905 \mathrm{NC}$; station $721 \mathrm{SJ}$ was transitional, and maximum flows increased from $589 K C$ downstream to the Missouri's terminus. Post-impoundment variability of annual maximum flows decreased at 3336FB, all inter-reservoir stations and the uppermost channelized-river site $(9910 M)$, increased at stations $905 \mathrm{NC}$ and $721 \mathrm{SJ}$ in the channelized section, but then decreased again at $589 \mathrm{KC}$ and downriver. Hydrologic alteration in annual maximum flows at least-altered stations ranged from $27 \%$ more years within the preregulation $25-75$ th\%ile than expected to $20 \%$ less years than expected. Most regulated river stations exhibited a greater alteration in medians of annual maximum flows than least-altered sites. Fewer years than expected were within the pre-regulation $25-75$ th $\%$ ile target range for 1- and 7-day (Figure 4) averaging

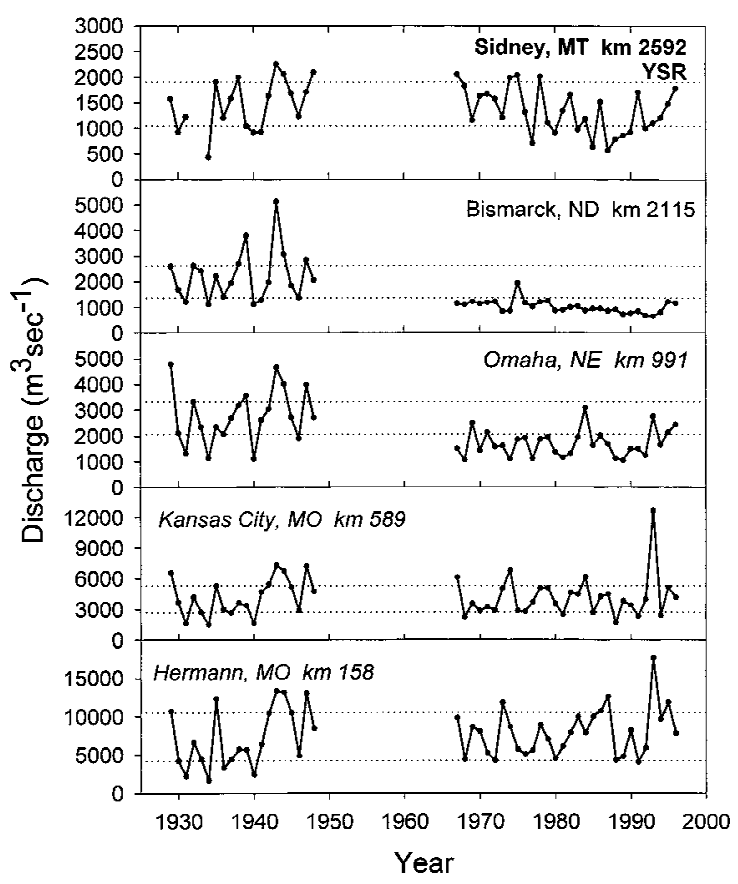

Figure 4. Annual 7-day median discharge at five stations along the Missouri and lower Yellowstone rivers (YSR) before (1929-1948) and after (1967-1996) flow regulation. The horizontal dotted lines identify a target range of variability for the post-regulation period. Refer to Figure 3 for further explanation.

periods of median annual maxima for inter-reservoir stations. The river from Kansas City $(589 \mathrm{KC})$ to the mouth showed a different trend with a higher number of post-regulation years falling within the target 25-75th\%iles of the 1-30-day averaging windows of maximum discharge than before flow regulation.

Post-regulation medians of annual minimum flows for 1-, 7- and 30-day averaging intervals at all study gauges were higher than pre-dam medians, over 100\% at many stations (Table 4, Figure 5). Locations with the smallest increases in annual minimum flows (although still ranging between 41 and 136\% higher) were the two least-altered sites and lowermost stations $317 \mathrm{BV}$ and $158 \mathrm{HM}$. Over $50 \%$ of post-dam years at all stations had fewer 1-, 7- and 30-day annual minimum flows within the pre-dam 25-75th\%iles than expected; all 30 post-dam years were above the target window for one or more of the annual minimum-flow durations at six of the inter-reservoir and channelized-river stations (Table 4, Figure 5). 
Table 4. Percent change in nonparametric (median, coefficient of dispersion) and parametric (mean, coefficient of variation) statistics and hydrologic alteration for five groups of hydrologic variables between pre- (Oct 1929-Sep 1948) and post-flow regulation (Oct 1967-Sep 1996) periods along the Missouri and lower Yellowstone (2592SN) rivers. All hydrologic parameters are summarized by nonparametric statistics except rise rate, fall rate and number of reversals, which are summarized by parametric statistics. Refer to Table 2 for station locations in relation to reservoirs. See Table 1 for definitions of hydrologic terms and text for how hydrologic alteration was calculated. JD = Julian date

\begin{tabular}{|c|c|c|c|c|c|c|c|c|c|c|c|c|c|c|c|c|}
\hline \multirow[t]{3}{*}{ Station } & \multicolumn{6}{|c|}{$\begin{array}{l}\text { Group } 2 \text { - Magnitude \& duration } \\
\text { of annual discharge extremes }\end{array}$} & \multicolumn{3}{|c|}{$\begin{array}{l}\text { Group } 3 \text { - Timing of } \\
\text { annual discharge } \\
\text { extremes }\end{array}$} & \multicolumn{4}{|c|}{$\begin{array}{l}\text { Group } 4-\text { Frequency \& } \\
\text { duration of high \& low } \\
\text { pulses }\end{array}$} & \multicolumn{3}{|c|}{$\begin{array}{l}\text { Group } 5 \text { - Rate \& } \\
\text { frequency of } \\
\text { hydrograph changes }\end{array}$} \\
\hline & \multicolumn{3}{|l|}{$\overline{\operatorname{Max}}$} & \multicolumn{3}{|l|}{ Min } & \multicolumn{2}{|c|}{ JD annual } & $\begin{array}{r}\overline{\text { JD Mar- }} \\
\text { Oct }\end{array}$ & \multicolumn{2}{|c|}{ High pulse } & \multicolumn{2}{|c|}{ Low pulse } & & & \\
\hline & $1 \mathrm{~d}$ & $7 d$ & $30 \mathrm{~d}$ & $1 d$ & $7 \mathrm{~d}$ & $30 \mathrm{~d}$ & Max & Min & Min & Count & Dur. & Count & Dur. & $\begin{array}{r}\text { Rise } \\
\text { rate }\end{array}$ & $\begin{array}{l}\text { Fall } \\
\text { rate }\end{array}$ & $\begin{array}{l}\text { No. flow } \\
\text { reversals }\end{array}$ \\
\hline & Medi & ean & & & & & & & & & & & & & & \\
\hline 3336FB & 30 & 27 & 33 & 69 & 41 & 51 & 3 & 34 & 14 & 100 & -21 & -11 & -77 & -15 & -17 & -6 \\
\hline 2738WP & -27 & -28 & -21 & 370 & 346 & 176 & -31 & -38 & 22 & 50 & -48 & -40 & -72 & -39 & -27 & 51 \\
\hline 2592SN & -12 & -23 & -12 & 126 & 102 & 51 & 4 & 8 & -3 & 0 & 24 & -17 & -45 & -33 & -34 & -4 \\
\hline 2115BM & -61 & -52 & -41 & 256 & 260 & 177 & -38 & -55 & 5 & 25 & -41 & 0 & -74 & -62 & -48 & 145 \\
\hline 1297YT & -59 & -52 & -34 & 144 & 148 & 149 & 95 & 48 & -48 & -50 & -3 & -75 & 76 & -76 & -62 & 56 \\
\hline $991 O M$ & -36 & -40 & -17 & 207 & 204 & 157 & 12 & 13 & -51 & -33 & -42 & -75 & 156 & -53 & -44 & 40 \\
\hline $905 N C$ & -21 & -29 & -12 & 174 & 186 & 124 & 1 & 12 & -29 & -17 & -31 & -78 & 101 & -42 & -40 & 30 \\
\hline $721 S J$ & 6 & -8 & -1 & 212 & 250 & 140 & 3 & 9 & -28 & 40 & 5 & -63 & 46 & -13 & -17 & 24 \\
\hline $589 K C$ & 15 & 1 & 5 & 163 & 179 & 126 & -1 & 7 & -30 & 0 & 17 & -63 & 16 & -6 & -11 & 19 \\
\hline $317 B V$ & 49 & 30 & 25 & 117 & 136 & 97 & 4 & 5 & -18 & 50 & 19 & -56 & -34 & 13 & 11 & 16 \\
\hline $158 H M$ & 21 & 38 & 53 & 91 & 94 & 100 & -1 & 7 & -21 & 60 & 20 & -33 & -34 & 14 & 13 & 14 \\
\hline
\end{tabular}

Coefficient of dispersion/coefficient of variation $(\mathrm{CD} / \mathrm{CV})$

$\begin{array}{lrrrrrrrrrrrrrrrr}\text { 3336FB } & -20 & -28 & -11 & -48 & -8 & -5 & 94 & -27 & 48 & 25 & 68 & -39 & 152 & 37 & 35 & -21 \\ \text { 2738WP } & -5 & -27 & -40 & -50 & -53 & -39 & -10 & 406 & 49 & 50 & 168 & 483 & 38 & -23 & 0 & -22 \\ \text { 2592SN } & -25 & 5 & 29 & 48 & 18 & -2 & -15 & 159 & 25 & 33 & 2 & 100 & 0 & -35 & -39 & -26 \\ 2115 \mathrm{BM} & -51 & -47 & -45 & -38 & -27 & 8 & 71 & 144 & 212 & 260 & 37 & 100 & -31 & -9 & 14 & -30 \\ 1297 \mathrm{YT} & -16 & -22 & -14 & 28 & -12 & -46 & -12 & 187 & 70 & 167 & 125 & 33 & 97 & 18 & 58 & 75 \\ 991 \mathrm{OM} & -1 & -13 & -15 & 30 & 2 & 7 & 7 & 60 & 84 & 250 & 315 & 60 & 314 & -4 & -11 & -28 \\ 905 \mathrm{NC} & 39 & 52 & 19 & 15 & -4 & 10 & 14 & -14 & 106 & 140 & 292 & 200 & 133 & 16 & 18 & -7 \\ 721 \mathrm{SJ} & 25 & 50 & 5 & -28 & -45 & -3 & 20 & 17 & 197 & 25 & 42 & 33 & 107 & 34 & 7 & -8 \\ 589 \mathrm{KC} & -36 & -16 & -8 & 16 & -18 & -15 & 149 & -14 & 252 & 25 & -58 & 100 & 81 & 15 & 9 & 10 \\ 317 \mathrm{BV} & -67 & -50 & -32 & 17 & 11 & 76 & 53 & 0 & 140 & 17 & -49 & 80 & 43 & -10 & -3 & -4 \\ 158 \mathrm{HM} & -46 & -47 & -51 & 34 & 46 & 1 & 168 & 125 & 115 & -22 & -45 & -200 & 60 & -20 & -20 & -6\end{array}$

Hydrologic alteration (HA)

\begin{tabular}{lrrrrrrrrrrrrrrrr} 
3336FB & -7 & 7 & -20 & -53 & -73 & -87 & -53 & -40 & -60 & -60 & -33 & 47 & -40 & -35 & -35 & 15 \\
2738WP & -40 & -40 & -33 & -100 & -100 & -100 & 13 & 80 & -67 & -27 & -47 & -80 & -53 & -30 & -15 & -70 \\
2592SN & 27 & 13 & -7 & -87 & -67 & -73 & -20 & 13 & -13 & 13 & 27 & -13 & -33 & 15 & 5 & 20 \\
$2115 \mathrm{BM}$ & -93 & -93 & -40 & -100 & -100 & -100 & -40 & 80 & -87 & -73 & 7 & -27 & -67 & -85 & -80 & -100 \\
$1297 \mathrm{YT}$ & -100 & -100 & -47 & -67 & -80 & -87 & -93 & -73 & -93 & -33 & -53 & -67 & -73 & -100 & -95 & -95 \\
$991 O M$ & -73 & -60 & 7 & -87 & -100 & -100 & -40 & -60 & -47 & -40 & -73 & -60 & -73 & -80 & -75 & -100 \\
$905 N C$ & -47 & -40 & 0 & -87 & -100 & -100 & -27 & -67 & -67 & -60 & -73 & -87 & -60 & -50 & -55 & -90 \\
$721 S J$ & -33 & -27 & 0 & -73 & -87 & -100 & -20 & -13 & -67 & -20 & -40 & -53 & -53 & -20 & 0 & -80 \\
$589 K C$ & 47 & 33 & 20 & -73 & -80 & -87 & -47 & 47 & -80 & -20 & 47 & -67 & -47 & 0 & 5 & -75 \\
$317 B V$ & 67 & 53 & 20 & -93 & -100 & -100 & -7 & 67 & -73 & -47 & 27 & -33 & -7 & 10 & 10 & -35 \\
$158 H M$ & 60 & 53 & 47 & -73 & -73 & -73 & -20 & 73 & -40 & -27 & 53 & -53 & -33 & 15 & 20 & -25 \\
\hline
\end{tabular}




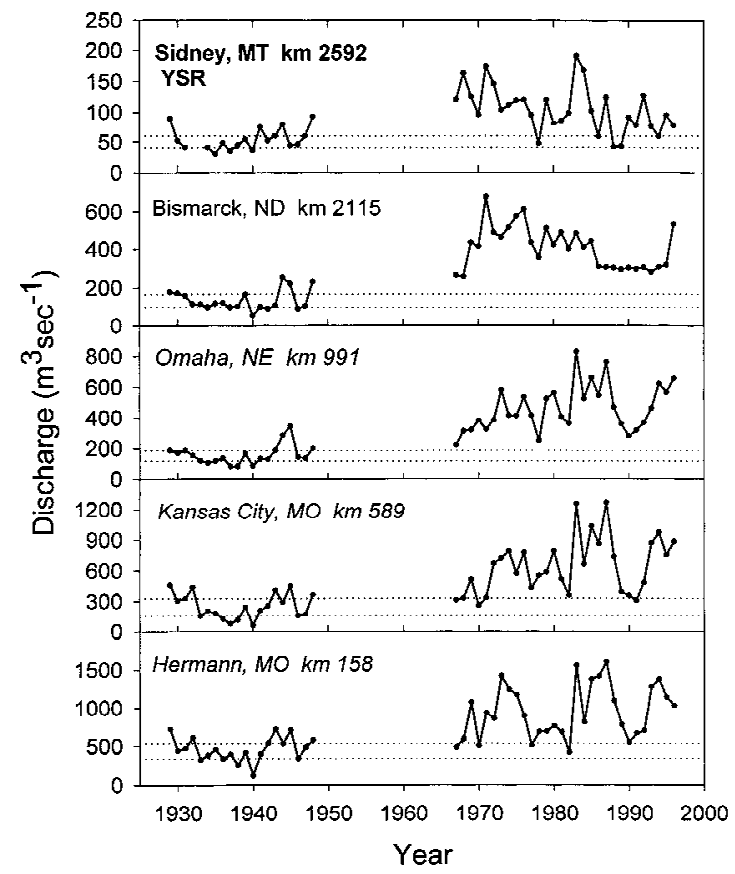

Figure 5. Annual minimum 7-day median discharge at five stations along the Missouri and lower Yellowstone rivers (YSR) before (1929-1948) and after (1967-1996) flow regulation. The horizontal dotted lines identify a target range of variability for the post-regulation period. Refer to Figure 3 for further explanation.

\section{Timing of annual discharge extremes}

Median date of the annual maximum daily discharge before flow regulation occurred within the same three weeks (21 May - 14 June, JD 142-166) among all stations except 1297YT (10 April). There were only small differences $(<4 \%)$ in timing of the median Julian date of annual daily flow maxima following regulation at above-reservoir stations and also in the channelized river from $905 \mathrm{NC}$ downriver (Table 4). However, variability in the date of annual maximum daily flow among years was generally higher in the channelized section following river impoundment (Table 4); fewer years than expected were within the pre-regulation 25-75th\%iles. Annual peak daily discharges occurred between 56 and 70 days earlier at inter-reservoir stations 2738WP and 2115BM, but 173 days later at station 1297YT below Gavins Point Dam, an important nesting area for federally threatened least terns (Smith, 1996).

Prior to flow regulation, annual daily discharge minima occurred between mid-December and early January (JD 345-4) at all stations except site 3336FB, where the median date of annual minimum daily discharge was 12 August. Median Julian date of annual flow minima occurred much earlier following dam operation at inter-reservoir stations 2738WP and $2115 \mathrm{BM}$, and $80 \%$ more post-regulation years than expected were within the pre-regulation 2575 th\%iles, even though variability in the timing of annual daily flow minima was much higher (Table 4). The gauge below Gavins Point Dam (1297YT) was again different from other inter-reservoir sites, as the timing of annual daily flow minima was delayed after flow regulation from Julian day 350 (15 December) to JD 71 (11 March) and 73\% fewer years than expected fell within the pre-regulation 25-75th\%iles. Variability in $\mathrm{CD}$ at channelized-river sites ranged from +60 to $-14 \%$, except at $158 H M$ where it increased to $125 \%$. Also, the percentage of post-regulation years within the pre-regulation 25-75th\%iles was higher than expected at the three lowermost channelized stations (Table 4).

Pre-dam median date of lowest daily flow between May and October occurred from JD 223 to 283 (10 August-9 October) at all stations, was most common in September (7 of 11 stations), and generally occurred later in the season farther downriver (October in the three lowermost stations). Timing of the 1967-1996 May-October daily flow minima was generally later than the 1929-1948 25-75th\%iles for stations 3336FB and 2738WP, was erratic at interreservoir station $2115 \mathrm{BM}$, and occurred much earlier in the growing season at station 1297YT and all sites downriver (Table 4).

Frequency and duration of annual high-and low-flow pulses

Discharges selected as the minimum threshold to define annual high pulses occurred in June at all Missouri River stations (Galat \& Lipkin, 1999). Leastaltered and inter-reservoir stations exhibited fewer (3-4 $\mathrm{yr}^{-1}$ ) high-flow pulses before flow regulation than channelized-river stations $\left(5-6 \mathrm{yr}^{-1}\right)$. The median number of high-flow pulses per year doubled at the Missouri River least-altered station 3336FB (from 3 to $6 \mathrm{yr}^{-1}$ ) between the two time intervals, but remained constant at the Yellowstone River least-altered station (2592SN). Frequency of high-flow pulses increased following flow regulation at inter-reservoir stations 2738WP and 2115BM; decreased at interreservoir and channelized stations 1297YT, 991OM and $905 N C$; and increased at three of the four lowerbasin channelized stations (721SJ, 317BV , 158HM). 


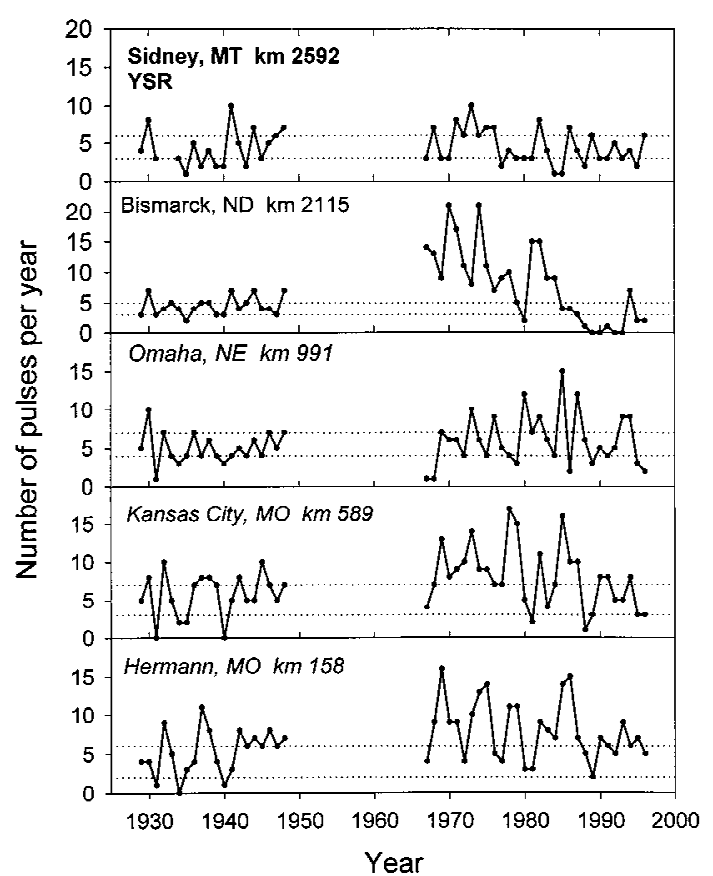

Figure 6. Number of high-flow pulses per year at five stations along the Missouri and lower Yellowstone rivers (YSR) before (1929-1948) and after (1967-1996) flow regulation. The horizontal dotted lines identify a target range of variability for the post-regulation period. Refer to Figure 3 for further explanation.

Variability in the number of high-flow pulses per year increased by over $100 \%$ following flow regulation at inter-reservoir and channelized-river stations 2115BM to $905 \mathrm{NC}$, compared to less than $35 \%$ at least-altered upper basin sites (Figure 6).

Median duration of high-flow pulses before impoundment ranged from 12 to 17 days $\mathrm{yr}^{-1}$ at stations 3336FB to $1297 \mathrm{YT}$ and decreased downriver to 7-9 days $\mathrm{yr}^{-1}$ at stations $9910 \mathrm{OM}-158 \mathrm{HM}$. After impoundment, the median duration of high-flow pulses decreased $(-3$ to $-48 \%)$ at 6 of the 7 stations between 3336FB and 905NC, except station 2592SN where it increased by $24 \%$. In contrast, the length of highflow pulses increased from 5 to $20 \%$ at the four lowermost channelized-river stations (721SJ-158HM) during 1967-1996. The number of days per year of high-flow pulses at the Yellowstone River site (2592SN) and the three lowermost channelized-river stations $(589 \mathrm{KC}, 317 \mathrm{BV}$ and $158 \mathrm{HM})$, were within the pre-regulation $25-75$ th $\%$ iles for over $60 \%$ of postregulation years. In summary, the number of high-flow pulses per year generally increased between the two time periods, but their length was shorter at the two least-regulated stations and the two upper river, inter-

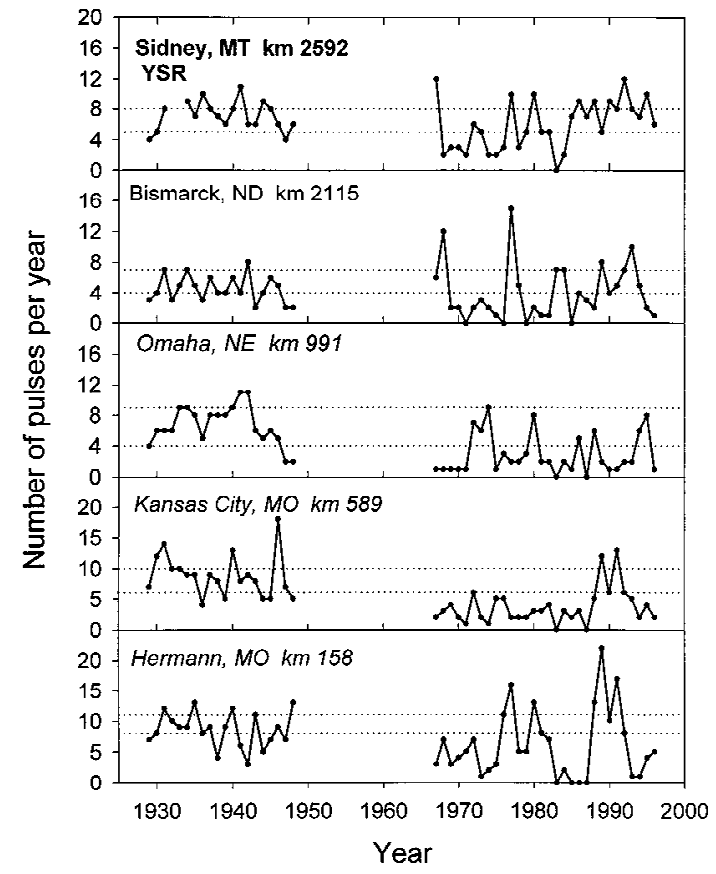

Figure 7. Number of low-flow pulses per year at five stations along the Missouri and lower Yellowstone rivers (YSR) before (1929-1948) and after (1967-1996) flow regulation. The horizontal dotted lines identify a target range of variability for the post-regulation period. Refer to Figure 3 for further explanation.

reservoir sites. Both the number and duration per year of high-flow pulses were reduced below Gavins Point Dam at station 1297YT, while their values generally increased between 1929-1948 and 1967-1996 at the four farthest downriver gauges ( $721 S J-158 H M)$.

The number of low-flow pulses per year decreased at 10 of the 11 stations following flow regulation (Table 4). This reduction was smallest at the two above-reservoir stations and at the lowermost river gauge $(158 \mathrm{HM})$. The post-dam decrease in number of low-flow pulses per year was highest ( -40 to $-78 \%)$ at inter-reservoir and channelized-river stations, with the exception of 2115BM (Figure 7). Variability in the number of low-flow pulses per year generally increased during the reservoir operation period, except at $158 \mathrm{HM}$ where the $\mathrm{CD}$ decreased. Fewer postregulation years than expected for most stations were within the 25-75th\%ile target range for the number of low-flow pulses, and the decrease in\%HA was lowest at least-altered site $\mathbf{2 5 9 2 S N}$.

Changes in the duration of annual low-flow pulses were recorded between pre- and post-regulation intervals, but were variable along the river continuum (Table 4). Duration following regulation was $45-77 \%$ 
shorter at the two above-reservoir stations and the two uppermost inter-reservoir gauges. Below Gavins Point Dam the pattern was reversed, duration increasing by over $75 \%$ at stations $1297 \mathrm{YT}, 9910 \mathrm{M}$ and $905 N C$. This increase was dampened downriver until it again decreased at the two lowermost stations $(317 \mathrm{BV}$, $158 H M)$. So, while there was a general basin-wide reduction in the number of low-flow pulses between the pre- and post-dam intervals, their duration showed a complex longitudinal pattern: decreasing, increasing and then decreasing again.

\section{Rate and frequency of change in discharge}

Rates of change in river flow were the only hydrologic parameters analyzed using parametric statistics and the pattern of results were similar for both discharge rises and falls (Table 4). Mean rates of discharge rises and falls were between 15 and 34\% lower and the mean number of flow reversals per year decreased slightly (4-6\% less) during 1967-1996 at the two least-altered stations. There was a more pronounced post-regulation reduction in rise and fall rates at interreservoir and upper channelized-river sites than at least-altered stations, and between 50 and $100 \%$ fewer years were observed within the pre-regulation \%HA target window at stations 2115BM to 905NC (Table 4). The post-regulation reduction became progressively less proceeding downriver from 1297YT to 721SJ$589 \mathrm{KC}$, while below $589 \mathrm{KC}(317 \mathrm{BV}$ and $158 \mathrm{HM})$ the mean rate of discharge change increased (Table 4). Additionally, 10-20\% of post-regulation years were within the pre-regulation target windows at the two lowermost sites, while between 50 and $100 \%$ fewer years than expected were within the target window at most regulated river stations upstream from $721 \mathrm{SJ}$.

More flow reversals per year were observed following regulation at stations downstream from dams, but this increase gradually diminished to only $14 \%$ more pulses per year after regulation at station $158 H M$. Similarly, the reversal rate per year between the two time periods was highest at inter-reservoir stations and decreased linearly downriver to $158 \mathrm{HM}$.

\section{Basin-wide summary}

Major differences in hydrologic indicators between pre- and post-regulation for the 11 stations are highlighted by reporting \%HA for hydrologic indicators ranked high or extreme (Table 5).

These include variables and stations where $>50 \%$ more post-regulation years than expected $(>22$ of the
30 post-regulation years for Groups 1-4) were within or outside of the RVA target window (25-75th\%ile for Groups 1-4, \pm 1 SD for Group 5).

Mean annual discharge for all stations along the Missouri River was higher from 1967 to 1996 than between 1929 and 1948, but noticeably less so at 2592SN, the only station with no upriver impoundments. Flow regulation of the mainstem Missouri River was associated with significant alterations in many of the 32 hydrologic indicators (Table 5). Most notably, these were: 1 . a reduction in the magnitude (i.e. lower high flows) and duration of the annual flood pulse; 2. an increase in the magnitude (i.e. higher low flows) and duration of annual discharge minima; 3. a reduction in the frequency of annual daily low-flow pulses and earlier timing of growing season daily low-flow pulses; and 4. a general increase in the frequency of discharge reversals per year coupled with a reduced rate of change in river flows. Collectively, hydrologic alterations were lowest at leastaltered station 2592SN, most severe at inter-reservoir and upper channelized-river sections, and intermediate at the lowermost channelized-river stations (Figure 8). Least-altered station 3336FB, below Canyon Ferry Reservoir, showed a composite hydrologic alteration much higher than least-altered site 2592SN and similar to that of the four lowermost channelized-river stations. Higher post-regulation discharge throughout most of the Missouri River catchment, but to a much lesser extent in the Yellowstone River basin, appeared to interact with reservoir operations to influence measures of hydrologic alteration between the two time intervals.

\section{Discussion}

Alterations in seasonal flow patterns and ecological effects

Our characterization of the Missouri River's flow regime between 1929 and 1948 shows the system to be more complex than previously reported (Hesse et al., 1989; Hesse \& Mestl, 1993). The protracted preregulation annual flood pulse in the lower Missouri River was a temporally cumulative result of complex precipitation and climatic patterns throughout the catchment: spring ice-out in the upper and middle basins, spring snowmelt in the middle basin, runoff from spring rains in the lower basin, and runoff from June snowmelt in the upper basin. We suspect the 


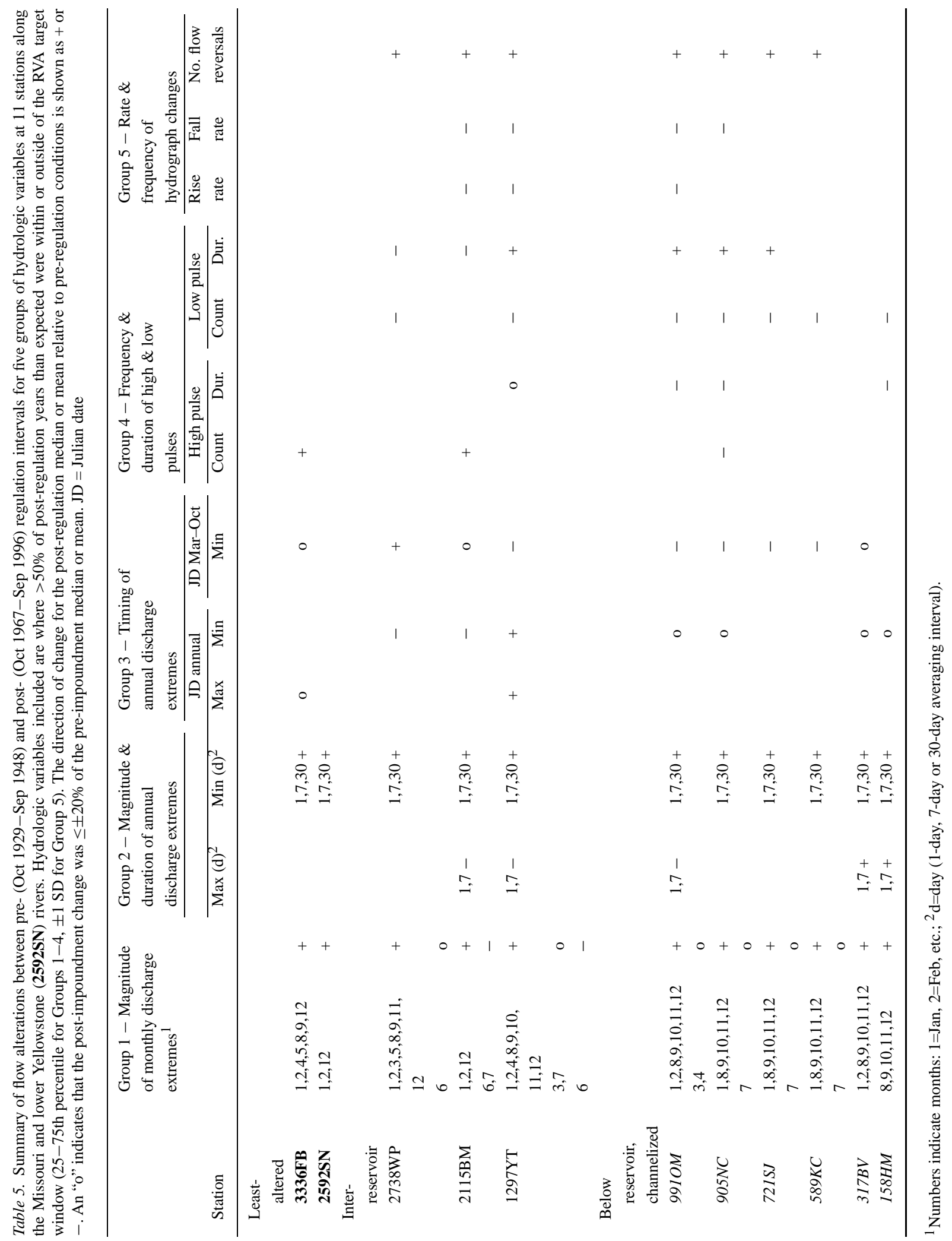


pre-regulation annual flow regime in the middle-river section was more bimodal than elsewhere because a spring rainy season is absent in the Great Plains Province.

The importance of a predictable annual flood pulse to reproduction of fishes in large floodplain rivers is well documented (Junk et al., 1989; Ward, 1989; Welcomme et al., 1989; Bayley \& Li, 1992) and is the basis of the 'flood-pulse advantage' observed in the high production of fishes in large river-floodplain systems (Bayley, 1991). If tenets of the flood-pulse concept are applicable to the Missouri River hydrosystem, we hypothesize that modifications in the magnitude, frequency, timing and duration of the annual flood pulse have reduced recruitment and production of native river-floodplain fishes in the inter-reservoir and channelized-river sections. Galat et al. (1998) showed that inundation for $\geq 10$ days of the Missouri River floodplain in central Missouri occurred during the optimal spawning temperature ranges of native fishes for only 4 of the 15 post-regulation years between 1983 and 1996.

There was historically a small fall increase in discharge along the lowermost Missouri River, similar to that reported by Sparks et al. (1990) and Sparks (1995) for the nearby upper Mississippi River. This small pulse is regional and due to the onset of autumn rains in the well-watered Central Lowlands and Interior Highlands physiographic provinces (Galat et al., 1998). A fall flow pulse is important to provide fishes access to wintering habitats on the floodplain and in backwaters before cold-water temperatures reduce their swimming ability (Bodensteiner \& Lewis, 1992). Furthermore, it inundated annual moist-soil vegetation in floodplain wetlands, providing forage to fall migrating waterfowl. This historically small autumn flow pulse inundated floodplain wetlands to a shallower depth than the subsequent large June pulse, with the result that forage remained available for waterfowl on their return migration the following spring (Sparks, 1992; Galat et al., 1998). Flow releases for navigation and levees that disconnect the lower Missouri River from its floodplain wetlands have largely eliminated this fall river rise and the benefits to fish and wildlife it once provided.

Assessment of intra-annual flow patterns also identified alteration of several ecologically important summer low-flow variables and showed that changes are widespread over the regulated Missouri River. Sustained reservoir water releases during the naturally low-water season cause protracted flooding of about two-thirds of the Missouri River and may be as pervasive and damaging a disturbance as reduction of the annual June flood pulse. Circumstantial evidence for this hypothesis comes from the native fish community that reproduces in or along the Missouri and lower Yellowstone rivers. Based on adult habitat use and reproductive requirements described in Pflieger (1971, 1997), we identified as 'fluvial specialists' $(*)$ seven of the nine fishes federally listed as candidate, threatened, or endangered (U.S. Fish \& Wildlife Service, 1994, 1995): Acipenser fluvescens, *Scaphirhynchus albus, Polyodon spathula, $*$ Hybognathus argyritus, $* H$. placitus, $*$ Macrhybopsis gleida, $*$ M. meeki, *Platygobio gracilis and $*$ Cycleptus elongatus. Fluvial specialists use flowing-water habitats throughout life (Bain, 1992; Kingsolving \& Bain, 1993). The remaining two species, A. fluvescens and $P$. spathula, are considered 'fluvial dependent,' requiring flowing water at some point in their life cycle (Bain, 1992; Kingsolving \& Bain, 1993). Both fishes reproduce in flowing waters and may migrate into tributary streams to spawn. All nine fishes are capable of completing their entire lifecycle within the channel complex and are included in Pflieger's (1971) 'Big River Faunal Group.' Loss of a river-floodplain connection due to a reduced annual flood pulse should have less direct affect on spawning success of these fishes than on floodplain-dependent species like centrarchids. Therefore, the disproportionate decline in Missouri River's native fluvial fishes appears most associated with protracted summer-fall high flows and in-channel habitat loss.

Loss of the lower Missouri River's braided channel geometry through channelization has eliminated most sand island and shallow in-channel habitats used by riverine fishes for spawning and nursery (Funk \& Robinson, 1974; Latka et al., 1993). The few low-elevation sand islands and associated shoals that remain are now flooded or their surface area reduced during much (July-September) of the reproductive season for many riverine fishes, as well as for birds and turtles (Galat et al., 1998) that make similar use of these critical habitats. Additionally, protracted summer-fall high flows prevent germination of early-successional tree species (Johnson, 1992) and moist-soil annual vegetation in suitable habitats that remain along the lower Missouri River.

This hypothesis regarding the ecological effects of altered summer-fall low flows is not intended to discount the importance of restoring the annual flood pulse, but to emphasize the need for the full range of seasonal flow variability to re-establish a natural- 
ized flow regime. The annual flood pulse is a critical cue to initiate spawning migrations for many fluvialspecialist and fluvial-dependent fishes, it is essential to transport floodplain-derived organic matter and nutrients to the main channel, and to maintain channelfloodplain geomorphic diversity (Welcomme, 1985; Junk et al., 1989).

\section{Natural factors contribute to spatio-temporal variability in river flows}

Station 2592SN on the Yellowstone River was the only site evaluated where no upstream mainstem impoundments were present and it showed the lowest degree of hydrologic alteration between the two time intervals (Figure 8). Proceeding downriver from the last mainstem dam, Gavins Point (km 1305), overall flow alteration between 1967 and 1996 declined from that observed at inter-reservoir sites. Hydrologic variability was less from $721 S J$ to the mouth than between the mainstem reservoirs and was similar to, or lower than, the upstream least-altered Missouri River site at 3336FB. However, sources of hydrologic alteration differed somewhat among the channelized-river stations and between them and 3336FB (Table 5). Notably, post-regulation magnitude and duration of annual maximum flows were higher at $317 \mathrm{BV}$ and $158 \mathrm{HM}$ than at other channelized sites because $317 \mathrm{BV}$ and $158 H M$ were more affected by climatically driven flooding in 1993, 1995 and 1996 (Parrett et al., 1993; Galat et al., 1998).

Flow differences were moderate to extreme comparing the 1929-1948 interval to 1967-1996 at all sites examined, including least-altered site 2592SN (Table 5). Consequently, caution must be used in attributing hydrologic alteration among sites and between the two time intervals solely to flow regulation. While mainstem impoundment, flow regulation, and changes in land use greatly influenced hydrologic variability of the Missouri River, at least two natural factors also contributed to these spatio-temporal differences. Basin-wide precipitation and runoff differed between the two time intervals, and hydrology is inherently variable along the Missouri River continuum.

The 'dust bowl' droughts of the 1930s occurred during the pre-regulation period and recurrent flooding in the 1990s was prevalent during the post-regulation interval. Qi Hu et al. (1998) analyzed interdecadal variations in precipitation from the 1890s through the 1990s in the central U.S., including the lower Missouri River basin states of Kansas, Nebraska, Iowa and Mis- souri. They concluded that there has been a trend in the region's annual mean precipitation and that it has changed from a decrease before the mid-1960s to an increase thereafter. Thus, the increase in low-flow discharge between 1967 and 1996, and most pronounced at inter-reservoir and channelized-river sites, appears to be an additive effect of mainstem flow regulation operating within the context of a catchment-wide increase in precipitation. This conclusion illustrates the importance of including least-altered sites in analyses of historical flow variability to normalize or filter out temporal climatic variation, even if such sites are not entirely anthropogenically unaltered.

A paradigm of the flood-pulse concept is that hydrologic buffering of a large catchment area results in smooth and predictable flooding and that effects of seasonal climatic changes are observed downstream only after several weeks or months in unaltered largefloodplain rivers in temperate and tropical regions (Junk et al., 1989). This has been shown graphically for the pre-regulation upper Mississippi (Sparks, 1992; Sparks et al., 1998) and Illinois rivers (Sparks, 1995). In contrast, timing of the pre-regulation median annual discharge maxima at 10 of 11 locations over the entire Missouri and lower Yellowstone rivers all occurred within 24 days and there was no longitudinal time lag. Additionally, IHA variables along the Missouri River continuum did not show a longitudinal decrease in predictability before flow regulation. Indices of dispersion (CD and CV, Tables 3 and 4) and the relative ranges of the pre-regulation $25-75$ th\%iles among stations (Figures 3-7) either showed no longitudinal pattern or upper - and lowermost - stations exhibited the greatest flow variability for most hydrologic indicators.

The Missouri River does not fit neatly into the flood-pulse concept because it arises in the well-watered Rocky Mountains and then flows over $1000 \mathrm{~km}$ through the semi-arid Great Plains. Consequently, its middle section is largely allogenic, analogous to a dryland river as described by Walker et al. (1995). Tributary influx to the Missouri River is greatest in the lowermost section, and variability in frequency and duration of high-flow pulses and discharge is also high here. Our assessment of 50 years of Missouri River hydrology illustrates that the influence of reservoir operations on the annual flood pulse was partially offset by tributary influx downriver from Kansas City $(589 \mathrm{KC})$ during the wet period of 1967-1996. Therefore, the flood pulse retains a more 


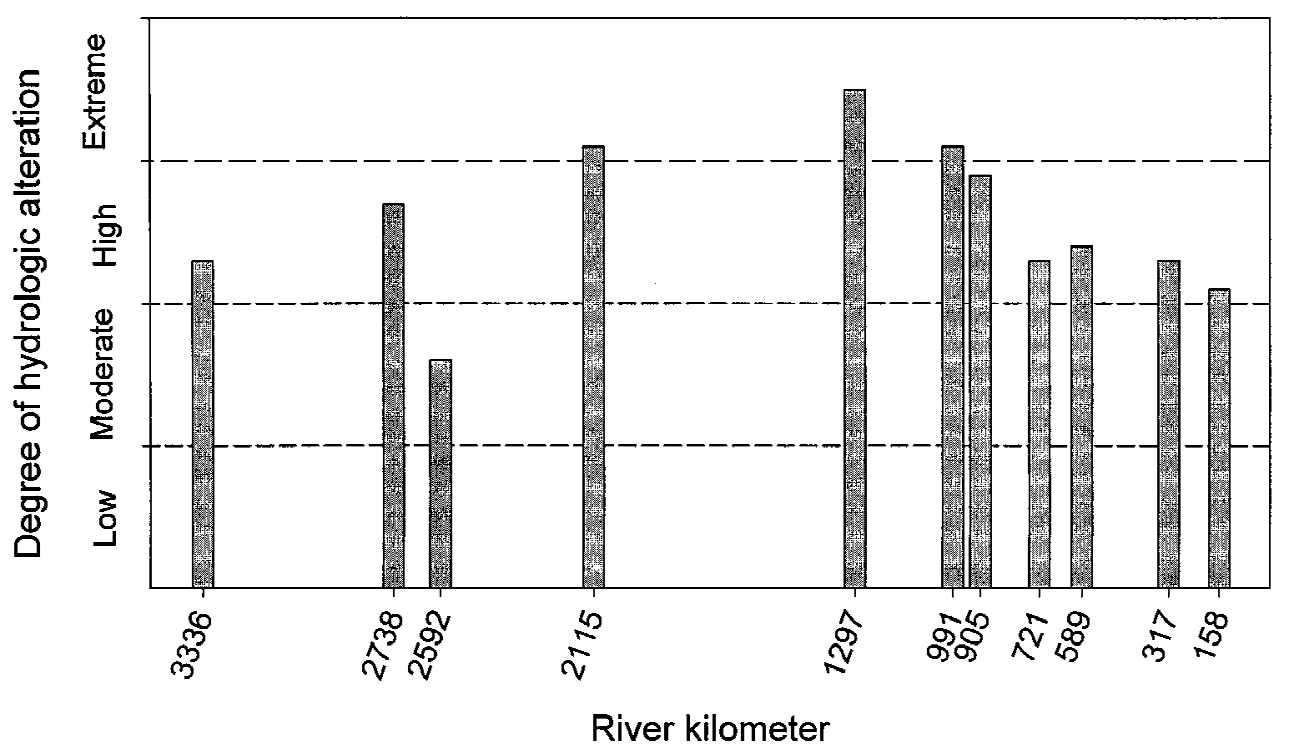

Figure 8. Ranked percentages of hydrologic alteration for the 1967-1996 post-regulation period averaged over five groups of hydrologic indicators for 11 stations along the Missouri and lower Yellowstone rivers. Hydrologic alteration occurs when the post-regulation median or mean of a hydrologic variable falls within the observed pre-regulation 25th to 75th percentiles or $\pm 1 \mathrm{SD}$, respectively, more or less often than expected. Low alteration indicates that annual values for the average of all groups of post-regulation hydrologic indicators fell within the observed pre-regulation range of hydrologic alteration $0-25 \%$ more or less often than expected, moderate: $26-50 \%$, high: $51-75 \%$, and extreme: $76-100 \%$.

natural character here than at upriver channelized and inter-reservoir locations.

Hughes (1995) recommended regional or ecoregional references to develop biological criteria for rivers. Our results support use of 'regional' rather than basinwide references, since distant locations were shown to be inappropriate spatial references for large rivers where natural longitudinal and geographic variability are great. Additionally, spatio-temporal differences in precipitation can confound the applicability of historical flow data for establishing baseline conditions. Prescribing initial flow targets from least-altered locations and historical discharge data at the landscape scale for large rivers maximizes use of available information. However, these sources are not without their shortcomings and, therefore, should be applied with caution, and not be the sole criteria for designing flow guidelines.

\section{Preliminary flow recommendations within an adaptive management framework}

The IHA and RVA methods are comprehensive techniques to assess the hydrological and, by inference, ecological integrity of running waters. A particular value of these methods is that they identify both increases and decreases in hydrologic variability and give high - and low - flow alterations equal weight. The idea of a human-induced disturbance as an alteration from the natural range of flow variation is bi-directional. River regulation that produces high flows during the historical low-flow season can have ecological consequences as harmful as an imposed reduction in the annual flood pulse. Reduced seasonal discharge variability through impoundment and flow regulation is evident today along much of the Missouri River (Figure 2). Additionally, channelization, bank stabilization, levee construction and changes in land use and land cover greatly influence the dischargestage relationship, river-floodplain hydrology, and habitat quality and availability. These factors also need to be considered when designing, implementing and refining flow-management guidelines. Restoration of a river's ecological integrity often requires rehabilitating and managing both flow and habitat.

Operational flexibility within the existing reservoir complex could be used to more closely approximate the 1929-1948 flow regime of the Missouri River in order to establish a 'simulated natural ecosystem' (sensu Schmidt et al., 1998). For example, target guidelines for Groups 1-4 variables are that 50\% of years should fall between the pre-regulation 25th and 75 th\%ile values (Figures 3-7), and for Group 5 
variables, $67 \%$ of the years should fall between the pre-regulation $-1 \mathrm{SD}$ and $+1 \mathrm{SD}$ values. Preliminary flow guidelines based on this approach are detailed in Galat \& Lipkin (1999) for each of the 32 hydrologic variables and for the nine flow-altered stations. Our results indicate that overall ecological structure and function of the inter-reservoir and upper channelizedriver sections would benefit by: 1 . controlled flooding through managed reservoir releases during June and July of some years; 2 . increasing the magnitude, frequency, and duration of annual high-flow pulses; and 3 . increasing the annual rate of hydrograph rises and falls. All of the regulated Missouri River would benefit from: 1. reducing reservoir discharges from August through February, 2. modifying the timing of reservoir releases, and 3. reducing the number of annual hydrograph reversals. These actions would increase the annual flood pulse, increase frequency and reduce monthly and annual low flows, delay timing of the growing season daily discharge minima and reduce the frequency of flow reversals per year. Assessment of ecological responses to a reregulation of Missouri River flows that more closely approximates the natural flow regime should then be used in an adaptive fashion to further adjust reservoir operations. Results summarized here and detailed in Galat \& Lipkin (1999) provide a first approximation of flow recommendations that approach the 1929-1948 range of variability of mainstem river flows throughout the Missouri River catchment.

Aspects of these ecologically based flow-management guidelines conflict with contemporary Missouri River reservoir management objectives of maximizing mid-summer power production in the inter-reservoir river and providing summer-autumn flow releases for navigation in the channelized river. Agency and public support for a more naturalized Missouri River hydrograph is increasing as the Missouri River Natural Resources Committee (Risland, 1999) is recommending a trial 'spawning rise' below Ft. Peak Reservoir. Flow releases from Lewis and Clark Reservoir to enhance the spring flood pulse are also under review by the U.S. Army Corps of Engineers (1998). Impoundment and flow regulation have provided large economic benefits by reducing annual flow extremes and increasing predictability of intermediate flows. In contrast, ecological systems benefit most from the full natural range of seasonal flows and associated uncertainty. We believe that the total economic value of the Missouri River will be higher when the traditional products of agriculture, electric-power generation and transportation are integrated with the socio-ecological benefits of a naturalized flow regime. We hope that consideration of the range of flow variability approach presented here and elsewhere (Richter et al., 1998) will stimulate discussion among the various beneficiaries within and outside the Missouri River basin to reconcile differences.

Analyses of hydrologic variability are needed on other river systems to better define the geographic diversity of natural and altered flow regimes. Such assessments will assist development of integrated and adaptive hydro-ecological models to predict a range of structural and functional responses of river-floodplain biota to various flow management scenarios within a framework of broader policy issues and societal values.

\section{Acknowledgements}

Chuck Smythe and Brian Richter assisted in application of the IHA and RVA methods. Thai Ngu contributed to the Figures, Pam Haverland assisted with data preparation, and Sandy Clark edited the manuscript. Lee Bergsted, Doug Dieterman, Robb Jacobson, Tom Parks, Mark Pegg, Brian Richter, Mike Ruggles and Robert White provided information and reviewed the manuscript. Funding was provided by the Missouri Department of Conservation to the University of Missouri. This article is a contribution from the Missouri Cooperative Fish and Wildlife Research Unit (U.S. Geological Survey-Biological Resources Division, Missouri Department of Conservation, University of Missouri and Wildlife Management Institute cooperating). We dedicate this paper to the memory of Tom Parks; we've lost a great friend to the Missouri.

\section{References}

American Rivers, 1997. North America's most endangered and threatened rivers of 1997. American Rivers, Washington, D.C.

Bacon, L. M. \& J. J. Rotella, 1998. Breeding ecology of interior least terns on the unregulated Yellowstone River, Montana. J. field Ornithol. 69: 391-401.

Bain, M. L., 1992. Study designs and sampling techniques for community-level assessment of large rivers. In Cuffney, T. F. \& M. E. Gurtz (eds), Biological Assessments in Large Rivers. 5th Annual Technical Information Workshop, N. am. Benthol. Soc., Louisville, KY: 63-74.

Bayley, P. B., 1991. The flood pulse advantage and the restoration of river-floodplain systems. Reg. Riv.: Res. Manage. 6: 75-86.

Bayley, P. B. \& H. W. Li, 1992. Riverine fishes. In Calow, P. \& G. E. Petts (eds), The Rivers Handbook. Vol. 1. Blackwell Scientific Publications, London, England: 251-281. 
Benke, A. C., 1990. A perspective on America's vanishing streams. J. n. am. Benthol. Soc. 9: 77-88.

Bodensteiner, L. R. \& W. M. Lewis, 1992. Role of temperature, dissolved oxygen and backwaters in the winter survival of freshwater drum (Aplodinotus grunniens) in the Mississippi River. Can. J. Fish. aquat. Sci. 49: 173-184.

Boon, P. J., P. Calow \& G. E. Petts, 1992. River conservation and management. Wiley \& Sons, Chichester.

Bravard, J.-P. \& G. E. Petts, 1996. Human impacts on fluvial hydrosystems. In Petts, G. E. \& C. Amoros (eds), Fluvial Hydrosystems. Chapman \& Hall, London, England: 242-262.

Calow, P. \& G. E. Petts, 1992. The rivers handbook. Blackwell Scientific Publications, London, England.

Copp, G. H., 1991. Typology of aquatic habitats in the Great Ouse, a small regulated lowland river. Reg. Riv.: Res. Manage. 6: 125134.

Davies, B. R. \& K. F. Walker (eds), 1986. The Ecology of River Systems. Dr W. Junk Publishers, Dordrecht.

Ferrell, J. R., 1993. Big dam era. Missouri River Division, U.S. Army Corps of Engineers, Omaha, NE.

Funk, J. L. \& J. W. Robinson, 1974. Changes in the channel of the lower Missouri River and effects on fish and wildlife. Aquatic Series 11, Missouri Department of Conservation, Jefferson City, MO.

Galat, D. L. \& A. G. Frazier (eds), 1996. Overview of RiverFloodplain Ecology in the Upper Mississippi River Basin. Vol. 3 of J. A. Kelmelis (ed.), Science for Floodplain Management into the 21st Century. U.S. Government Printing Office, Washington, D.C.

Galat, D. L. \& R. Lipkin, 1999. Characterizing the natural flow regime of the Missouri River using historical variability in hydrology. Missouri Cooperative Fish \& Wildlife Research Unit. Univ. of Missouri, Columbia.

Galat, D. L. \& 16 coauthors, 1998. Flooding to restore connectivity of regulated, large river wetlands. BioScience 48: 721-733.

Gore, J. A. (ed.), 1985. The Restoration of Rivers and Streams. Butterworth Publishers, Boston, MA.

Gore, J. A. \& F. D. Shields, 1995. Can large rivers be restored? BioScience 45: 142-152.

Hedman, E. R. \& D. G. Jorgensen, 1990. Surface and ground-water interactions and hydrologic budget of the Missouri River valley aquifer between Yankton, South Dakota, and St. Louis, Missouri. Atlas HA-721, U.S. Geological Survey, Denver, CO.

Hesse, L. W. \& G. E. Mestl, 1993. An alternative hydrological cycle for the Missouri River based on the pre-control condition. N. am. J. fish. Manage. 13: 360-366.

Hesse, L. W., J. C. Schmulbach, J. M. Carr, K. D. Keenlyne, D. G. Unkenholz, J. W. Robinson \& G. E. Mestl, 1989. Missouri River fishery resources in relation to past, present and future stresses. Can. Spec. Publ. Fish. aquat. Sci. 106: 352-371.

Hughes, R. M., 1995. Defining acceptable biological status by comparing with reference conditions. In Davis, W. S. \& T. P. Simon (eds), Biological Assessment and Criteria: Tools for Water Resource Planning. Lewis Publ., Boca Raton, FL: 31-47.

Johnson, B. L., W. B. Richardson \& T. J. Naimo, 1995. Past present and future concepts in large river ecology. BioScience 45: 134 141.

Johnson, W. C., 1992. Dams and riparian forests: case study from the upper Missouri River. Rivers 3: 229-242.

Junk, W. J., P. B. Bayley \& R. E. Sparks, 1989. The flood pulse concept in river-floodplain systems. Can. Spec. Publ. Fish. aquat. Sci. 106: 110-127.

Karr, J. R. \& E. W. Chu, 1999. Restoring life in running waters: better biological monitoring. Island Press, Washington, D.C.
Kingsolving, A. D. \& M. B. Bain, 1993. Fish assemblage recovery along a riverine disturbance gradient. Ecol. Appl. 3: 531-544.

Latka, D. C., J. Nestler \& L. W. Hesse, 1993. Restoring physical habitat in the Missouri River: a historical perspective. In Hesse, L. W., C. B. Stalnaker, N. G. Benson \& J. R. Zuboy (eds), Restoration Planning for the Rivers of the Mississippi River Ecosystem. Biol. Rep. 19, National Biological Survey, Washington, D.C.: 350-359.

Michener, W. K. \& R. A. Haeuber, 1998. Flooding: natural and managed disturbances. BioScience 48: 677-680.

National Research Council, 1992. Restoration of Aquatic Ecosystems. National Academy Press, Washington, D.C.

Parrett, C., N. B. Melcher \& R. W. James Jr., 1993. Flood discharges in the upper Mississippi River basin, 1993. U.S. Geological Survey Circular 1120-A, Denver, CO.

Pflieger, W. L., 1971. A distributional study of Missouri fishes. Univ. Kansas Pubs., Mus. Nat. Hist. 20: 225-570.

Pflieger, W. L., 1997. The fishes of Missouri. Missouri Dept. Conservation, Jefferson City. Poff, N. L. \& 7 coauthors, 1997. The natural flow regime. BioScience 47: 769-784.

Poizat, G. \& D. Pont, 1996. Multi-scale approach to species habitat relationships: juvenile fish in a large river section. Freshwat. Biol. 36: 611-622.

Qi, Hu, C. M. Woodruff \& S. E. Mudrick, 1998. Interdecadal variations of annual precipitation in the central United States. Bull. am. Meteorol. Soc. 79: 221-229.

Reash, R. J., 1998. Considerations for characterizing midwestern large-river habitats. In Simon, T. P. (ed.), Assessing the Sustainability and Biological Integrity of Water Resources Using Fish Communities. CRC Press, Boca Raton, FL: 463-473.

Richter, B. D., J. V. Baumgartner, D. P. Braun \& J. Powell, 1998. Assessing hydrological connectivity within river ecosystems. Reg. Riv.: Res. Manage. 14: 329-340.

Richter, B. D., J. V. Baumgartner, J. Powell \& D. P. Braun, 1996. A method for assessing hydrological alteration within ecosystems. Conserv. Biol. 10: 1163-1174.

Richter, B. D., J. V. Baumgartner, R. Wigington \& D. P. Braun, 1997. How much water does a river need? Freshwat. Biol. 37: 231-249.

Risland, S., April, 1999. Summary of the Kansas City MRBA Conference. In The Missouri River Report. Missouri River Basin Association, Lewistown, MT: 2-8.

Schmidt, J. C., R. H. Webb, R. A. Valdez, G. R. Marzolf \& L. E. Stevens, 1998. Science and values in river restoration in the Grand Canyon. BioScience 48: 735-747.

Schmulbach, J. C., L. W. Hesse \& J. E. Bush, 1992. The Missouri River - Great Plains thread of life. In Becker, C. D. \& D. A. Nietzel (eds), Water Quality in North American River Systems. Batelle Press, Columbus, OH: 137-158.

Scott, M. L., G. T. Auble \& J. Friedman, 1997. Flood dependency of cottonwood establishment along the Missouri River, Montana, U.S.A. Ecol. Appl. 7: 677-690.

Shields, R. R., M. K. White, P. N. Ladd, C. L. Chambers \& K. A. Dodge, 1997. Water resources data, Montana, Water Year 1997, Water-data Report MT-97-1, U.S. Geological Survey, Helena, MT.

Smith, J. W., 1996. Wildlife use of the Missouri and Mississippi River basins - an ecological review. In Galat, D. L. \& A. G. Frazier (eds), Overview of River-Floodplain Ecology in the Upper Mississippi River Basin. Vol. 3 of J. A. Kelmelis (ed.), Science for Floodplain Management into the 21st Century. U.S. Government Printing Office, Washington, D.C.: 91-112.

Sparks, R. E., 1992. Risks of altering the hydrologic regime of large rivers. In Cairns Jr., J. B. R. Niederlehner \& D. R. Orvos (eds), 
Predicting Ecosystem Risk. Vol. XX: Advances in Modern Environmental Toxicology. Princeton Scientific Publ. Co., Princeton: $119-152$.

Sparks, R. E., 1995. Need for ecosystem management of large rivers and their floodplains. BioScience 45: 168-182.

Sparks R. E., J. C. Nelson \& Y. Yin, 1998. Naturalization of the flood regime in regulated rivers. BioScience 48: 706-720.

Sparks, R. E., P. B. Bayley, S. L. Kohler \& L. L. Osborne, 1990. Disturbance and recovery of large floodplain rivers. Envir. Manage. 14: 699-709.

Stanford, J. A., J. V. Ward, W. J. Liss, C. A. Frissell, R. N. Williams, J. A. Lichatowich \& C. C. Coutant, 1996. A general protocol for restoration of regulated rivers. Reg. Riv.: Res. Manage. 12: 391-413.

U.S. Army Corps of Engineers, 1998. Missouri River Master Water Control Manual. Review and Update, Preliminary Revised Draft Environmental Impact Statement. U.S. Army Corps of Engineers, Northwestern Division, Missouri River Region, Omaha, NE.

U.S. Fish \& Wildlife Service, 1994. Endangered and threatened wildlife and plants; animal candidate review for listing as endangered or threatened species; Proposed rule. Dept. Interior, Fish \& Wildlife Service, Federal Register, 50 CFR Part 17, 50(219): 58982-59028.

U.S. Fish \& Wildlife Service, 1995. Endangered and threatened wildlife and plants. Dept. Interior, Fish \& Wildlife Service, Federal Register, 50 CFR Parts 17.11 \& 17.12: 1-44.

Walker, K. F., F. Sheldon \& J. T. Pukridge, 1995. A perspective on dryland river ecosystems. Reg. Riv.: Res. Manage. 11: 85-104.

Ward, J. V., 1989. Riverine-wetland interactions. In Sharitz, R. $\&$ J. Gibbons (eds), Freshwater Wetlands and Wildlife. CONF8603101, DOE Symposium Series No. 61, U.S. Dept. of Energy, Office of Scientific and Technical Information, Oak Ridge, TN: 385-399.

Welcomme, R. L., 1985. River fisheries. FAO Fisheries Technical Paper 262. Food \& Agr. Organization of the United Nations, Rome.

Welcomme, R. L., R. A. Ryder \& J. A. Sedell, 1989. Dynamics of fish assemblages in river systems - a synthesis. Can. Spec. Publ. Fish. aquat. Sci. 106: 569-577.

White, R. G. \& R. G. Bramblett, 1993. The Yellowstone River: its fish and fisheries. In Hesse, L. W., C. B. Stalnaker, N. G. Benson \& J. R. Zuboy (eds), Restoration Planning for the Rivers of the Mississippi River Ecosystem. Biol. Rep. 19, National Biological Survey, Washington, D.C.: 396-414.

Whitmore, S. B. \& K. D. Keenlyne, 1990. Rare, threatened and endangered endemic species of the Missouri River floodplain. Report MRC-90-1, U.S. Fish \& Wildlife Service, Missouri River Coordinator's Office, Pierre, SD. 